\title{
PROVINCIA-ENTIDAD LOCAL Y COMUNIDADES AUTONOMAS UNIPROVINCIALES
}

353.072 .1

por

\author{
José-Luis Martínez López-Muñiz \\ Profesor Adjunto de Derecho Administrativo \\ Universidad de Oviedo
}

SUMARIO: I. INTRODUCCION: 1. LA POSIBILIDAD DE COMUNIDADES AUTÓNOMAS UNIPROVINCIALES EN EL PROCESO DE ELABORACIÓN DE LOS ARTí́CULOS 143 y 144 DE LA CONSTITUCIÓN. 2. LA CREACIÓN EFECTIVA DE ENTES PREAUTONÓMICOS REGIONALES UNIPROVINCIALES. 3. Problemas QUe plantea la constitución de una Comunidad AUTÓNOMA DE ÁMBITO UNIPROVINCIAL. 4. LÍNEAS DE SOLUCIÓN APUNTADAS EN LOS REGÍMENES PREAUTONÓMICOS UNIPROVINCIALES. 5. EL Proyecto de Estatuto de Autonomía de Asturias.-II. NATURALEZA DE LA PROVINCIA EN LA NUEVA CONSTITUCION ESPAÑOLA: 1. ENTIDAD aDMINISTRATIVA local aUTÓNOMA. 2. DE DERECHO NECESARIO Y NATURALEZA CONSTITUCIONAL. 3. SU DELIMITACIÓN TERRITORIAL ES MATERIA RESERVADA A LEY ORGÁNICA. 4. CORPORACIÓN INTERADMINISTRATIVA TERRITORIAL DETERMINADA POR AGRUPACIÓN LEGAL DE MUNICIPIOS: A) Fundamento constitucional de esta caracterización; B) El carácter intermunicipal de la Provincia en el proceso de elaboración del texto constitucional; C) Precedentes de esta configuración de la Provincia; D) Consecuencias en cuanto al procedimiento electoral provincial; E) Análisis del tema en el régimen foral de Navarra "amejorado" en 1979; 
F) La cuestión en las Provincias Vascongadas; G) Régimen especial de las Provincias insulares.-III. LAS COMUNIDADES AUTONOMAS UNIPROVINCIALES: FUNDAMENTO Y JUSTIFICACION: 1. SU FUNDAMENTO CONSTITUCIONAL. 2. SU FUNCIONALIDAD JURÍDICA: A) Superior rango constitucional del derecho regional a la autonomí; B) Carácter paccionado del Estatuto de Autonomia; C) La potestad legislativa; D) La ampliación de competencias administrativas $y$ de recursos económicos; E) Especiales derechos constitucionales de participación cooperativa en el Estado; F) Tribunal Superior de Justicia para el territorio regional; G) Control y garantía de su autonomía por el Tribunal Constitucional; H) Diferencias en los controles de la Administración estatal sobre Administraciones locales y Comunidades Autónomas.-IV. NATURALEZA MIXTA PROVINCIAL-REGIONAL DE LAS COMUNIDADES AUTONOMAS UNIPROVINCIALES: 1. Provincias y CoMUNidades Autónomas PLURIPROVINCIALES. 2. LAS Provincias-COMUNIDADES AUTÓNOMAS: ESTRUCTURA PROVINCIAL Y RÉGIMEN REGIONAL.-V. CONCLUSION.

\section{INTRODUCCION}

1. La POSIBILIDAD DE COMUNIDAdES AUtónomas UNIPROVINCIALES EN EL PROCESO DE ELABORACIÓN DE LOS ARTÍ́culos 143 Y 144 DE LA CONSTITUCIÓN

En la sesión del 13 de junio de 1978 de la Comisión de Asuntos Constitucionales y Libertades Públicas del Congreso de los Diputados, un Diputado del Partido Socialista de Aragón, integrado en el Grupo Parlamentario Mixto, don Emilio GASTÓN SANZ, defendía muy brevemente una enmienda in voce al artículo 130 del anteproyecto de Constitución aprobado por la Ponencia, antecedente del definitivo artículo 137 del texto constitucional e indirectamente de otros de sus preceptos.

El artículo 130, redactado por la Ponencia con el voto a favor de los Grupos de U. C. D. y A. P. y en contra de los Grupos Comunistas y Minoría Catalana, decía así:

"El Estado se organizará en Municipios. La Provincia se fundamenta sobre la asociación de Municipios en los términos que determine la 
ley. Las Comunidades autónomas se basan en la libre asociación de las Provincias. Todas estas Entidades gozan de autonomia para la gestión de sus respectivos intereses»(1).

La enmienda del señor GASTón fue defendida en los siguientes términos:

«... creo que ha habido un lapsus y se ha olvidado una cosa.

Se dice concretamente que las Comunidades autónomas se basan en la libre asociación de Provincias, y no se dice nada más. $\mathrm{Y}$ yo lo que he presentado es: 'o de la constitución como tal de una sola Provincia', porque se dan los casos de Asturias, que muy pronto va a ser, y de Baleares, que creo que lo va a ser también, y desde luego no son asociación de Provincias, ni están previstas estas asociaciones dentro de los casos especiales que se prevén en el artículo 140, en el que se dice que las Cortes Generales, mediante ley orgánica, podrán, por motivo de interés nacional, autorizar la constitución de una Comunidad autónoma cuyo ámbito territorial no supere al de una Provincia, y otros casos especiales. Pero el de una Provincia sólo no se da. Por tanto, lo que yo he sugerido es simplemente que se incluya esto, que creo que ha sido una omisión involuntaria» (2).

En nombre de la Ponencia, intervino de inmediato el señor Roca JUNYENT para aclarar que el supuesto que quería recoger el señor GASTÓN estaba efectivamente contemplado o incluido en el artículo 140, a), aprobado por la Ponencia (3). Pero ciertamente este precepto exigía ya la autorización de las Cortes Generales por medio de una Ley orgánica, sin la cual no podría ponerse en marcha la correspondiente iniciativa autonómica.

En realidad, al recomponer todo el primitivo texto del título VIII del anteproyecto de 5 de enero de 1978, que parecía admitir la posibilidad de que una sola Provincia se constituyera en Territorio Autónomo (4), la Ponencia estableció que, en principio, las Comunida-

(1) Cfr. BOC, núm. 82, 17 abril 1978, 1596.

(2) Cfr. $D S$, núm. 87,13 junio 1978,3226 . Se ha transcrito el texto tal y como aparece en el $D S$. Parece contener algún error de imprenta.

(3) Cfr. ibidem.

(4) El Título VIII del anteproyecto de 5 de enero de 1978 se iniciaba con un artículo 128, que decía que: «1. Para el ejercicio del derecho a la autonomía a que se refiere el artículo $2 .^{\circ}$ de la Constitución, las diferentes Nacionalidades y Regiones que integran España podrán acceder a su autogobierno y constituirse en Territorios Autónomos (...)». Como se ve, los sujetos del derecho a la autonomía eran directamente las comunidades regionales (o nacionalitarias), sin mediación alguna de las Provincias, a diferencia de lo que introducirá la Ponencia de la Comisión Constitucional del Congreso. Por otra parte, en el artículo 129 del mismo anteproyecto se atribuía la iniciativa del proceso autonómico «a los Ayuntamientos de una o varias Provincias limitrofes o territorios insulares con características historicas o culturales comunes". 
des Autónomas se formarían por asociación de Provincias, por lo que las excepciones a este principio debian ser expresamente autorizadas por las Cortes Generales con carácter previo, mediante una ley de las características cualificadas que serían propias de las leyes orgánicas.

La enmienda del señor GASTón SANZ no fue planteada acertadamente, pues es claro que una Comunidad Autónoma uniprovincial quedaba de lleno bajo la previsión del 140, a), por cuanto su ámbito territorial no superaría, por definición, el de una Provincia. Para estar justificada y tener sentido tenía que haber propuesto algún criterio claro para extraer de las previsiones del 140,a), y reconducir al supuesto general y normal de las Comunidades Autónomas, los casos de Regiones uniprovinciales en que él pensaba. Su intervención fue útil, sin embargo, al permitir que quedara constancia expresa en el Diario de Sesiones de la intención de la Ponencia al aprobar los artículos mencionados.

$\mathrm{Al}$ artículo 136 del texto de la Ponencia, antecedente del actual 143, el señor GASTón SANZ había presentado también una enmienda similar in voce, pero dirigida certeramente esta vez a lograr que la Comunidad Autónoma uniprovincial fuera prevista como supuesto normal. Pero la retiró y renunció a defenderla, para apoyar la enmienda que en parecido sentido propuso el P.S.O.E. (5).

En efecto, en una intervención inmediatamente posterior, el Grupo Parlamentario Socialista, por boca del señor Sotillo MarTí, defendería una enmienda in voce, proponiendo la siguiente redacción:

"En el ejercicio del derecho a la autonomía, reconocido en el artículo 2.: de la Constitución, las Provincias limítrofes con características históricas, culturales y económicas comunes, los territorios insulares y las Provincias con entidad regional histórica, podrán acceder a su auto gobierno y constituirse en Comunidades autónomas con arreglo a lo previsto en este título $y$ en los respectivos Estatutos»(6).

Basta comparar el tenor de esta enmienda con el texto del definitivo artículo 143, 1, de la Constitución, para comprobar el éxito

La mediación se atribuía a los Municipios y parece claro que se admitía la Región uniprovincial. Cfr. BOC, núm. 44, 5 enero 1978, artículos citados.

(5) Cfr. DS, núm. 88, 14 junio 1978, 3254.

(6) Cfr. DS, cit., supra, 3254-55. El texto de la Ponencia decía: «1. Las Provincias limitrofes con características históricas, culturales y económicas comunes y los territorios insulares podrán asociarse entre sí en Comunidades Autónomas». (Cfr. BOC, número 82, 17 abril 1978, 1597. 
pleno que obtuvo en este punto el Grupo Socialista. La enmienda fue aprobada en la Comisión por 30 votos a favor, dos en contra y sin abstenciones (7); y los votos en contra lo fueron únicamente por las connotaciones que para los representantes de A. P. implicaba la referencia explícita al artículo $20^{\circ}$ de la Constitución (8).

Justificando la enmienda, señaló el señor Sotıllo que:

«Por último, la tercera posibilidad es la Provincia o las Provincias con entidad regional histórica, entendido que la utilización plural no es una utilización en sentido técnico, sino en sentido figurado, por cuanto se está refiriendo a la posibilidad de Comunidad autónoma uniprovincial, en el sentido que lo ha planteado algún compañero de $\mathrm{Co}$ misión, pero que consideramos que debe matizarse con la expresión 'entidad regional histórica', a fin de ofrecer seguridad jurídica y de evitar también extralimitaciones en este sentido. Creo que todos tenemos en la mente cuál puede ser esta última posibilidad. Sin ir más lejos, todos reconocemos que una Provincia como Asturias posee, evidentemente, una entidad regional histórica, y el cauce debe abrirse para ella a través de la Constitución, en su reconocimiento como Comunidad autónoma. Y así podríamos citar algún otro caso especialísimo de la realidad de nuestro país» (9).

Evidentemente, aun cuando no se dijo entonces expresamente, la trascendencia de la aceptación de esta enmienda era que el artículo $140, a$ ), de la Ponencia quedaba ahora recortado: no se aplicaría a las Provincias con entidad regional histórica, porque éstas, por ser Regiones, tendrían derecho a constituirse en Comunidades Autónomas normalmente, sin especiales autorizaciones de las Cortes.

La posibilidad de que, aparte de las Provincias insulares (10), determinadas Provincias, en las que pudiera reconocerse esa entidad regional histórica, se acogieran al régimen general para constituirse en Comunidades Autónomas, quedaba asi definitivamente admitida, sin lugar a posible duda.

Además, el definitivo artículo $144, a$ ), recogería la posibilidad del $140, a)$, antes citado, de la Ponencia, con la adición que, en buena

(7) Cfr. DS, núm. 88, 14 junio 1978, 3257.

(8) Cfr. $D S$, cit., supra, 3258, explicación de voto del señor FraGA.

(9) Cfr. DS, cit., supra, 3255.

(10) La expresión "territorios insulares», de ser identificable con la noción de archipiélagos, admitiría la constitución en Comunidad Autónoma de la Provincia de Baleares, pero no de cada una de las Provincias Canarias, ya que el conjunto de las islas que llevan este nombre formarian en este sentido un solo "territorio». Ahora bien, desde el momento en que alguno de los «territorios insulares» coincide con una Provincia, es claro que la Constitución estaba admitiendo el acceso al autogobierno en forma de Comunidad Autónoma a esa Provincia insular, aunque no tuviera «en. tidad historica regional», y por el procedimiento general. 
lógica, propuso el señor MEILÁN GiL para acordar este texto con el del actual 143, 1 (11). Es decir, además de las Comunidades Autónomas uniprovinciales para Provincias de entidad regional histórica, cabrán Comunidades Autónomas uniprovinciales-o incluso de ámbito inferior al provincial-si las Cortes Generales autorizan la puesta en marcha del correspondiente proceso autonómico mediante Ley orgánica.

\section{LA CREACIÓN EFECTIVA DE ENTES PREAUTONÓMICOS REGIONALES UNIPROVINCIALES}

Por lo demás, el peculiar fenómeno paralelo al proceso constituyente que ha sido la sucesiva creación por Decreto-ley de los llamados Entes preautonómicos, corresponde fielmente a esa posibilidad de Comunidades Autónomas uniprovinciales que reconocería la Constitución.

En efecto, dejando aparte el régimen preautonómico para el Archipiélago Balear, aprobado por Real Decreto-ley núm. 18, de 13 de junio de 1978, puesto que se trata de una Provincia insular y su posibilidad de constitución en Comunidad Autónoma estaba ya incluso contemplada en el artículo 136 de la Ponencia, aunque no respondiera exactamente a la definición de Comunidad Autónoma que trazaba el artículo 130, aprobado por la misma Ponencia, hay que recordar los Reales Decretos-leyes núms. 29 y 30, de 27 de septiembre de 1978, por los que se aprobaron los regímenes preautonómicos de Asturias y de Murcia, aplicables en ambos casos a las respectivas Provincias de Oviedo y Murcia, como señala el artículo 2. de ambas normas legales.

Quizás casualmente, pero puede ser destacado, el Real Decretoley que institucionaliza el Consejo Interinsular Balear es firmado por el Rey el mismo día que en la Comisión Constitucional del Congreso el señor GASTÓN SANZ planteaba su enmienda in voce relativa a las Comunidades Autónomas uniprovinciales. El Consejo de Ministros había aprobado ese Decreto-ley en su reunión del 2 de junio y saldría publicado en el Boletín Oficial del Estado del 30 del mismo mes. En cuanto a los regímenes preautonómicos de Asturias y Murcia, fueron acordados por el Gobierno el 25 de agosto, cuando ya

(11) Cfr. DS, núm. 90, 15 junio 1978, 3310. 
había sido aprobado el proyecto constitucional por el Pleno del Congreso.

Ocioso es recordar que, en virtud de la disposición transitoria primera del texto constitucional-tal y como fue aprobado ya por el Congreso-se reconocería a los órganos preautonómicos la capacidad de asumir en sustitución de Diputaciones provinciales y órganos interinsulares la iniciativa del procedimiento de constitución de las correspondientes Regiones en Comunidades Autónomas. Ello implicaba la sanción constitucional como auténticas Regiones-en este caso Provincias con "entidad regional histórica»-de aquellas comunidades territoriales que ya dispusieran de régimen preautonómico.

\section{Problemas que plantea la constituctón de una Comunidad AUTÓNOMA DE ÁMBITo UNIPROVINCIAL}

Pues bien, desde el mismo momento en que nuestro ordenamiento pasa a admitir que una sola Provincia se constituya en Comunidad Autónoma por entenderse que históricamente ha sido y es una Región, por tratarse de un territorio insular, o bien, porque, autorizándolo las Cortes Generales mediante Ley orgánica, se considera que reúne condiciones para reconocerse en adelante como Región con derecho a autonomía, se plantean varios problemas: ¿La constitución de la Comunidad Autónoma uniprovincial se llevará a cabo mediante un proceso de conversión o transformación de la Entidad provincial hasta ahora existente? ¿No habrá de respetarse más bien la Provincia con su entidad propia, constituyéndose a su lado y con independencia de ella la nueva Comunidad Autónoma? ¿Cómo se articularán en este último caso las relaciones entre Provincia y Comunidad Autónoma?, y, en fin, si la alternativa es la primera, esto es la conversión de la Entidad provincial en Comunidad Autónoma, $¿$ cuáles son las condiciones que obligan en su caso a respetar nuestro ordenamiento jurídico para que esa transformación resulte admisible?

Evidentemente estará en juego en todo momento en estas cuestiones el tema de si la Entidad local provincial es o no en nuestra Constitución de derecho necesario y hasta qué punto o en cuáles de sus elementos. Enmarcará asimismo todo el problema el hecho de que no parece muy racional la superposición de dos entidades públicas territoriales que extiendan su competencia sobre la misma 
población asentada en el mismo territorio, y que justifiquen de modo semejante su existencia en su carácter democráticamente representativo de la misma comunidad social provincial-regional por cuyos intereses peculiares se proponen velar.

\section{LÍNEAS DE SOLUCIÓN APUNTADAS EN LOS REGÍMENES PREAUTONOMICOS UNIPROVINCIALES}

A este respecto, y aunque se trata de entidades puramente administrativas y provisionales, cabe recordar el criterio seguido en la creación de los Consejos Regionales de Asturias y Murcia, en septiembre de 1978. En estos regímenes preautonómicos se mantienen, como es sabido, las respectivas Entidades provinciales con sus correspondientes Diputaciones, las cuales están a su vez integradas o representadas en la composición de los Consejos Regionales (12) y adquieren el deber de prestar su colaboración para la ejecución de los acuerdos de éstos (13). Los Consejos Regionales gestionarán y administrarán las funciones y servicios que les transfiera la Administración del Estado (14) y pueden proponer al Gobierno cuantas medidas afecten a los intereses de la respectiva Región (15). A diferencia de otros regímenes prautonómicos, ni siquiera se prevé en éstos la posibilidad de transferencia de funciones de las Diputaciones a los Consejos Regionales. Se establece, en cambio, el deber de ambos organismos de informarse recíprocamente sobre sus respectivos planes y programas (16). En las exposiciones de motivos de los Decretos-leyes 29 y 30, de 27 de septiembre de 1978, se explica, sin embargo:

«Especialmente se han regulado las relaciones de colaboración y coordinación del Consejo Regional y la Diputación, distinguiendo la fase anterior y la posterior a las elecciones locales, marcándose así la tendencia a que, en el posible Estatuto de Autonomía, ambos organismos se refundan en uno solo."

(12) Cfr. art. $4 .^{\circ}$ de ambos Reales Decretos-leyes.

(13) «Para la ejecución de sus acuerdos, el Consejo Regional de Asturias (de Murcia), sin perjuicio de sus propios servicios, podrá utilizar los medios personales y materiales de la Diputación Provincial, la cual prestará la colaboración necesaria para la ejecución de sus acuerdos» (art. 8. ${ }^{\circ}$ de ambos Reales Decretos-leyes).

(14) Cfr. art. $5 .^{\circ}, b$ ), de ambos Reales Decretos-leyes.

(15) Cfr. art. $\left.50^{\circ}, d\right)$, de ambos Reales Decretos-leyes.

(16) Cfr. art. $\left.5 .^{\circ}, c\right)$, de ambos Reales Decretos-leyes. 
Las diferencias de regulación antes y después de las elecciones locales atañen fundamentalmente, como se sabe, a la muy distinta presencia de los representantes de la Diputación en el Consejo Regional. Antes de las mencionadas elecciones sólo un Diputado o representante de la Diputación; después, en Asturias, un número de Diputados igual al número de parlamentarios de la Región, y, en Murcia, todos los Diputados provinciales. Además, antes de las elecciones locales, en Asturias el representante de la Diputación no podía intervenir en la elección del Presidente del Consejo Regional, mientras que, después, todos los miembros del Consejo habrían de adquirir igualdad de derechos (17).

Todo esto nos revela una clara tendencia a evitar la duplicidad de entidades y organismos al mismo nivel provincial-regional, que, con todo, se ha aceptado provisionalmente en esta fase preautonómica, aparte de otras posibles razones, por una impaciente estrategia política de los partidos políticos ganadores en las elecciones de junio de 1977. Considerándose entonces que las Diputaciones provinciales estaban aún vinculadas en exceso a tendencias políticas que se estimaban derrotadas en aquella consulta electoral, se resolvió prescindir de ellas a la hora de arbitrar un centro receptor de las amplias medidas descentralizadoras que habrían de preparar el advenimiento de la autonomía regional constitucional. Y en vez de tratar de utilizarse las grandes virtualidades institucionales de las Provincias en cuanto Entidades locales, y de sus Diputaciones, se crearon, un tanto artificiosamente, los Consejos Regionales, manteniéndose aquéllas.

Dirección parcialmente distinta se siguió en cambio en el Archipiélago Balear, donde se aprovecharía la oportunidad de la instalación del llamado régimen preautonómico para llevar a cabo una auténtica transformación del régimen local provincial abandonando el régimen común y adoptando un régimen especial similar al de las Provincias Canarias. El Real Decreto-ley 18, de 13 de junio de 1978, crea, en efecto, el Consejo General Interinsular como órgano de gobierno de Baleares con competencia para gestionar y administrar las funciones y servicios que le transfieran la Administración del Estado y en su caso la Diputación provincial, buena parte de las cuales podrían delegarse en los Consejos Insulares de Mallorca, Menorca e Ibiza-Formentera, que también se creaban por este mismo

(17) Cfr. art. $4 .^{\circ}$ de ambos Reales Decretos-leyes. 
Decreto-ley (18). Hasta las elecciones locales solamente habría de constituirse, y provisionalmente, el Consejo General Interinsular, con miembros elegidos por los parlamentarios de Baleares, teniendo cada isla por lo menos tres representantes (19). La puesta en marcha definitiva de las nuevas instituciones se aplazaba a las elecciones locales, debiendo regular la ley correspondiente lo necesario para ello. Y, efectivamente, la Ley de Elecciones locales de 17 de julio de 1978, además de regular la composición de los nuevos organismos, como tendremos ocasión de analizar más adelante, vino a determinar la plena sustitución de la Diputación Provincial de Baleares por los Consejos Insulares y por el Consejo Interinsular (20). Superados, pues, los problemas políticos de la subsistencia de las Diputaciones elegidas en época de Franco, la Ley se decidía resueltamente en Baleares por la transformación del régimen común de la Provincia en un régimen especial adaptado a las características insulares, sobre el cual habría de montarse además el proceso de descentralización propio de las preautonomías. En realidad la misma Entidad provincial, aunque organizada no en base a una Diputación, sino en base a un órgano representativo distinto y liberada de muchas funciones por descentralización en Entidades inferiores de tipo comarcal cuales son las Islas, se convertía en sujeto receptor de la preautonomía al mismo tiempo que continuaba con parte de sus antiguas funciones propias.

\section{El Proyecto de Estatuto de Autonomía de Asturias}

Por lo demás, y volviendo a la tendencia a la refundición de organismos provinciales-regionales que se declara en las exposiciones de motivos de los Decretos-leyes creadores de las preautonomías asturiana y murciana, no está claro sobre qué Entidad y con qué características habrá de llevarse a cabo. A título indicativo, sin embargo, cabe anotar que en el Proyecto de Estatuto de Autonomía de Asturias, aprobado por la correspondiente Asamblea estatuyente-

(18) Cfr. arts. $3 .^{\circ}, 4 .^{\circ}$ y $\left.5 .^{\circ}, c\right)$ y $d$ ).

(19) Cfr art. $4 .^{\circ}$ in fine y disposición transitoria.

(20) Cfr. Ley de Elecciones locales, arts. 39 y 40. 
proponente (21) asturiana el 12 de abril de 1980 (22), se declara paladinamente en el artículo $1 .^{\circ}, 3$, que

"Las funciones de gobierno y administración autónoma de la actual Provincia de Oviedo son asumidas por el Principado de Asturias" (23).

El Principado de Asturias es, según el mismo artículo $1 .^{\circ}, 2$, la Comunidad Autónoma que se constituye en Asturias, cuyos órganos se especifican en los artículos 19 y siguientes sin mención alguna a la Diputación, cuyas competencias y medios, en virtud del artículo 17, pasarán al Principado. Una disposición transitoria quinta atiende a resolver técnicamente los problemas de la refundición de la Corporación Provincial en la nueva Comunidad Autónoma.

$¿$ Qué juicio merecen estas soluciones desde un punto de vista de estricta constitucionalidad? ¿Pueden considerarse plenamente acordes con las normas y principios de nuestra Constitución? Es ésta la cuestión principal que hemos de analizar seguidamente, sin perjuicio de que puedan hacerse sobre el tema otro tipo de consideraciones $u$ observaciones de índole diversa, señaladamente desde perspectivas de política administrativa, económica, etc., que pueden resultar aquí más o menos marginales.

Solventar estos interrogantes requería establecer primero claramente la naturaleza de la Provincia-Entidad local en nuestra Constitución e indagar seguidamente la razón de ser de una Comunidad Autónoma uniprovincial. Desde el conocimiento de ambas instituciones así alcanzado, las posibles soluciones al problema de su recíproca articulación han de fluir fácilmente (24).

(21) Doy esta denominación a la Asamblea a que se refiere el artículo $146 \mathrm{dc}$ la Constitución, encargada de elaborar y elevar a las Cortes Generales el proyecto de Estatuto de las Comunidades Autónomas que se constituyan por la vía ordinaria del. artículo 143 y ss. La composición de esta Asamblea es muy similar a la de los Consejos Regionales de Asturias y Murcia en su fase post-elecciones locales de 1979 y a la de la generalidad de los Entes preautonómicos, aunque en la mayor parte de los casos la Asamblea resultará más numerosa que los Plenos de los órganos preautonómicos. Pero el principio organizador es similar: presencia, por una parte, de los Diputados o miembros de la Corporación o Corporaciones provinciales, y, por otra, de los Diputados y Senadores en Cortes por la Provincia o Provincias respectivas.

(22) El texto del Proyecto del Estatuto asturiano puede consultarse en Revista Iuridica de Asturias, 2, julio-diciembre 1979, 175-202.

(23) Inversamente-aunque con una significación puramente territorial y no institucional-el artículo 2. ${ }^{\circ}$ del Real Decreto de 30 de noviembre de 1833 había establecido: "El Principado de Asturias forma la Provincia de Oviedo».

(24) A lo largo del trabajo emplearemos únicamente el término Región para referirnos tanto a las Regiones como a las Nacionalidades a que reconoce derecho a la autonomía, dentro de la unidad solidaria de la Nación española, el artículo $2 .^{\circ}$ de la Constitución. Entendemos que las Nacionalidades, en el sentido nuevo que ha que- 


\section{NATURALEZA DE LA PROVINCIA EN LA NUEVA CONSTITUCION ESPAÑOLA}

\section{ENTIDAD ADMINISTRATIVA LOCAL AUTÓNOMA}

La Constitución, sancionando las líneas generales de nuestra tradición institucional contemporánea y dando un paso más en su evolución progresiva, reconoce el doble carácter que en nuestro Derecho público tiene la Provincia como "división territorial para el cumplimiento de las actividades del Estado» y como "Entidad local con personalidad jurídica propia» (artículo 141,1), pero añade que como tal Entidad goza de "autonomía para la gestión de sus intereses" (artículo 137, in fine).

Por comparación con el artículo 45, II, de la derogada Ley Fundamental Orgánica del Estado de 1967, cabe destacar:

a) Que como división territorial, lo es para el cumplimiento de cualesquiera actividades del Estado y no solamente de la Administración del Estado, que es lo que constitucionalizaba la citada Ley.

b) Que, por fin, se prescinde de la oscura expresión que calificaba a la Provincia como circunscripción-a la vez que como división territorial-y se le da la denominación adecuada de Entidad local, constitucionalizándose además su personalidad jurídica expresamente, cosa que ciertamente ya hacía también la Ley Orgánica del Estado en el artículo 46, I.

En definitiva, la Provincia se nos presenta en la Constitución sobre todo como una persona jurídica administrativa, integrante básica, junto con los Municipios, de la Administración local, y dotada de una autonomía que parece habrá de llevar a la liquidación de los mecanismos de tutela hasta ahora existentes, al menos en

rido darse a este término por los-constituyentes, son una especie del género Región caracterizada por la acentuada intensidad con que se presenta en la psicología colectiva de la correspondiente comunidad territorial la vivencia del hecho diferencial regional. Es de destacar que jurídicamente la Constitución no conecta en forma directa consecuencia relevante alguna a la distinción entre Regiones (simpliciter) y Nacionalidades. La tesis de que Nacionalidades serán las comunidades territoriales a que se refiere la disposición transitoria segunda del texto constitucional, no puede mantenerse como interpretación rigurosamente fundada en criterios estrictamente jurídicos. En todo caso, hipotéticamente, cabría aplicar ese discutible término de Nacionalidades a cuantas Regiones lograran abrirse paso y constituirse en Comunidades Autónomas por el procedimiento del artículo 151, que con el referéndum de iniciativa exige demostrar un extendido y vivo deseo autonómico. 
cuanto a las funciones que la ley le atribuya como propias (25). Como Entidad local que es, se le aplica el Ordenamiento jurídicoadministrativo local, que, en diversos puntos, sigue presentando algunas diferencias con respecto al Ordenamiento administrativo de la Administración del Estado, y que, en el futuro, podrá ser elaborado, en parte, por los Legislativos de las distintas Comunidades Autónomas, en su caso.

La Constitución se refiere también a la Provincia como circunscripción electoral en las elecciones al Congreso (artículo 68, 2). Me parece que en este sentido la Provincia es reconducible a su acepción como división territorial para el cumplimiento de actividades del Estado. Más confusamente se refiere también a la Provincia el artículo 69 de la Constitución, relativo a las elecciones al Senado. Esta Cámara comienza por ser calificada como Cámara de representación territorial, pero seguidamente se monta su composición en base a dos tipos distintos de Senadores: los provinciales y los designados por Comunidades Autónomas, aparte los que corresponde elegir a las poblaciones de Ceuta y Melilla. En cada Provincia se elegirán cuatro Senadores, afirma el apartado 2 de este artículo 69, pero por el mismo sufragio universal, libre, igual, directo y secreto, con arreglo al cual deben elegirse también los Diputados del Congreso. Hay sin embargo una diferencia apreciable y es que mientras el artículo 68 impone un criterio de proporcionalidad en las elecciones al Congreso, nada dice al respecto el artículo 69 en cuanto a la elección de los Senadores provinciales. El tema tendrá que regularse en una ley orgánica (artículo 69, 2, in fine), pero de momento, por aplicación de la disposición transitoria octava, núm. 3, de la misma Constitución, sigue en vigor el ordenamiento electoral derivado de la Ley Fundamental para la Reforma Política de 4 de enero de 1977, cuya disposición transitoria primera, base segunda, estableció criterios de escrutinio mayoritario en las elecciones a Senadores.

En cualquier caso, y a diferencia de lo que claramente establece el mismo artículo 69, 5, para los Senadores por las Comunidades Autónomas, puede afirmarse que las referencias a las Provincias contenidas en este artículo a propósito de la elección de Senadores no difieren en su significación de las que emplea el artículo 68 a propósito de las elecciones al Congreso. Es decir, puede entenderse que

(25) Vid. Bocanegra Sierra, R.: Nueva configuración de la tutela sobre las Corporaciones locales, «DA», núm. 182, abril-junio 1979, 367-393. 
se trata también aquí de la Provincia-división territorial y no de la Provincia-Entidad local. Como máximo cabría afirmar que la Constitución está contemplando la comunidad social asentada en la correspondiente división territorial, pero sin mediación alguna de la Provincia-Entidad local, propiamente dicha, ya que, como hemos de ver, el conjunto de la población provincial, tomado unitariamente, no constituye en realidad elemento ni órgano alguno de la Entidad provincial.

\section{DE DERECHO NECESARIO Y NATURALEZA CONSTITUCIONAL}

Ciñéndonos ya a la Entidad local-Provincia y aunque concretamente estas características de que ahora tratamos son también atribuibles a la circunscripción territorial correspondiente del Estado, es evidente su rango constitucional, en cuanto establecida y básicamente regulada en la Constitución.

Ciertos preceptos parecen además indicar que la Constitución contempla a la Provincia como una institución ciertamente necesaria, de la que no puede prescindir ninguna porción del territorio y de la población española, salvo excepción expresamente prevista por la misma Constitución. El artículo 137 afirma así que "el Estado se organiza territorialmente en Municipios, en Provincias y en las Comunidades Autónomas que se constituyan. Todas estas Entidades gozan de autonomía para la gestión de sus respectivos intereses", lo que se entiende en el sentido de que la cobertura total del territorio por Municipios y Provincias es un imperativo constitucional, mientras que no lo es respecto de las Comunidades Autónomas. Por otra parte, el artículo 141, 1, parece establecer una unión inseparable entre la Entidad local provincial y la Provincia división territorial del Estado, y, al menos desde su funcionalidad electoral, no parece que pueda haber porción alguna del territorio nacional que no esté integrada en una Provincia, como no sea el de Ceuta y Melilla, excepción expresamente prevista en el artículo 68, 2, y concordantes de la Constitución (26).

(26) Sostiene esta misma tesis sobre la obligatoriedad y no contingencia de la Provincia-Entidad local, Entrena Cuesta, R.: Curso de Derecho Administrativo, I-1, 6. ed., Tecnos, Madrid, 1979, 32-35. donde reproduce lo expuesto ya en Concepto y estructura de la Administración pública en la Constitución, en «Libro homenaje al Profesor Galvañ Escutía», Valencia, 1979. 


\section{SU DELIMITACIÓN TERRITORIAL ES MATERIA RESERVADA}

\section{A LEY ORGÁNICA}

La Constitución no ha querido mantener rígidamente la actual división provincial, pero ha impuesto a la vez una exigencia procedimental para toda alteración de sus términos, que deroga la posibilidad abierta en la Ley de Régimen local a través de la alteración de términos de Municipios de Provincias limítrofes, para la que bastaba la aprobación del Consejo de Ministros siguiéndose el procedimiento del artículo 20 de la Ley de Régimen local (27), y aumenta la dificultad general para alterar los límites provinciales. En efecto, si hasta ahora el artículo 205, 2, de la Ley de Régimen local exigía una ley para alterar dichos términos, ahora el artículo 141, 1, in fine, de la Constitución exige una Ley orgánica.

La posibilidad de modificación de la actual división provincial no debe considerarse sin embargo despreciable, pues flexibiliza de modo destacable la posible dureza del carácter necesario de esta institución local intermedia. De todos modos, la relevancia electoral que la Constitución otorga a la Provincia complicará y dificultará probablemente la realización de cualquier proyecto de remodelación provincial, que de otro modo podría resultar más viable, para supuestos en que la realidad socioeconómica, administrativa y política pudieran aconsejarla.

\section{CORPORACIÓN INTERADMINISTRATIVA TERRITORIAL DETERMINADA} POR AGRUPACIÓN LEGAL DE MUNICIPIOS

\section{A) Fundamento constitucional de esta caracterización}

Tocamos ahora uno de los puntos característicos esenciales de la Provincia que más relevancia habrá de tener en la solución a los problemas planteados en este trabajo en relación con la articulación de la Entidad provincial con una eventual Comunidad Autónoma uniprovincial coincidente con ella en población y territorio.

El texto constitucional nos dice de la Provincia expresamente:

a) Que es Entidad determinada por la agrupación de Municipios (artículo 141, 1);

(27) Cfr. Ley de Régimen local, art. 205, 1 y 2. 
b) Que se podrán crear agrupaciones de Municipios diferentes de la Provincia (artículo 141, 3), pero, claro está, tan agrupaciones de Municipios como ella;

c) Que son las Cortes Generales mediante Ley orgánica, según ya dijimos, quienes tienen que aprobar cualquier alteración de los límites provinciales (artículo 141, 1), y, en consecuencia, quienes agrupan a los Municipios en Provincias, por lo que se comprueba que en la Constitución la Provincia se configura como agrupación legal de Municipios. Los Municipios no se asocian o se separan libremente, sino que resultan forzosamente asociados en Provincias por ley-y por Ley orgánica en concreto-en base a un imperativo constitucional;

d) Que las Provincias tienen, como los Municipios y las Comunidades Autónomas que se constituyan, naturaleza territorial, formando parte esencial y necesaria, según vimos, de la organización territorial de la comunidad nacional constituida en Estado (artículos 137 y 133, 2, en relación con el artículo 142) (28). En este sentido se diferencian claramente de las Mancomunidades voluntarias y Agrupaciones forzosas de Municipios reguladas en la legislación de Régimen local (29). Tienen fines generales-los intereses generales de la colectividad provincial-, potestades públicas propias de los entes territoriales, etc., a diferencia de esas otras Entidades que tienen naturaleza "institucional» en el sentido de no territorial, a pesar de ser también Corporaciones de segundo grado.

Del conjunto de estos elementos aportados por la Constitución misma resulta cabalmente la caracterización de la Provincia-Entidad local como Corporación-asociación dotada de potestades públicas propias (30)-, interadministrativa-en cuanto resulta de la

(28) Vid. al respecto GuAItA, A.: División territorial y descentralización, IEAL, Madrid, 175, 24 y ss., y García de EnTERríA. E., y Fernández. T. R.: Curso de Derecho Administrativo, I, 3.2 ed., Civitas, Madrid, 1980, 317-319, que aceptan limitada y críticamente la tesis de NiETo, A.: Entes territoriales y no territoriales, "RAP», 64 , enero-abril 1971, 29-51. Me ocupé del tema bajo el Derecho positivo anterior en Los Consorcios en el Derecho español: análisis de su naturaleza juridica, IEAL, Madrid, 1974, 274 y ss.

(29) Cfr. actualmente Real Decreto 3046. de 6 de octubre de 1977, por el que se aprueba el texto articulado parcial de la Ley 41/1975 de Bases del Estatuto del Régimen local, arts. 10 y ss. Para la legislación anterior, vid. MARTínez López-MuÑIZ, I. L.: Los Consorcios..., cit., 388 y ss., y 495 y ss.

(30) Sobre el concepto de Corporación, vid. Garrido Falla, F.: Tratado de Derecho Administrativo, I, reimpr. 7. ed., CEC, Madrid, 1980, 367-368; García-TREVIJANO Fos, I. A.: Tratado de Derecho Administrativo, II-1, Ed. RDP, 2.2 ed., Madrid, 1971, 292 y 344; García de EnTerría, E., y Fernández, T. R.: Curso..., I, citado, 319 y ss. 
asociación o agrupación de esos entes administrativos que son los Municipios-, territorial-representativa de una colectividad territorial municipalmente estructurada, cuyos intereses generales trata de satisfacer, disponiendo para ello de potestades administrativas máximas-y legal -en cuanto formada por la fuerza de la ley. Se distingue por consiguiente tanto de las Corporaciones interadministrativas no territoriales (31) como de las Corporaciones que, como los Municipios y las Entidades públicas corporativas de base sectorial privada (32), tienen como elemento personal de su constitución intrínseca personas individuales y no personas jurídicas o entes colectivos, concretamente de naturaleza administrativa. Pero pueden recibir con toda propiedad la calificación de Corporaciones interadministrativas, ya que, en efecto, quienes resultan asociados en las Provincias son los Municipios (33), cuya naturaleza de Administraciones públicas con personalidad jurídica propia nadie discute y la propia Constitución confirma.

Resumiendo, pues, todo esto con otras palabras podemos afirmar que la Provincia-Entidad local se configura en nuestra Constitución como una Corporación territorial intermunicipal. En realidad su origen y carácter legal es algo que puede considerarse implícito en la territorialidad.

\section{B) El carácter intermunicipal de la Provincia en el proceso de elaboración del texto constitucional}

Pero veamos un poco más detenidamente los antecedentes de la fórmula constitucional del artículo 141 para asegurarnos mejor en la interpretación que acabamos de hacer.

Como hemos indicado en las primeras líneas de este mismo trabajo, el artículo 130 del anteproyecto constitucional aprobado por la Ponencia de la Comisión de Asuntos Constitucionales del Congreso decía expresamente, con rotundidad y con fórmula inédita en nuestros textos constitucionales y legales, que

"La Provincia se fundamenta sobre la asociación de Municipios en los términos que determine la ley."

(31) Cfr. Martínez López-Muñiz, J. L.: Los Consorcios..., cit., 167 y s., 229, 270 y s., 447, etc., y García de EnTERría, E., y Fernández, T. R.: Curso..., I, citado, 333 y ss.

(32) Cfr. García de Enterría, E., y Fernández, T. R.: Curso..., I, cit., 328.

(33) Cfr. en el mismo sentido Boquera Oliver, J. M.": Derecho Administrativo, 3." ed., IEAL, Madrid, 1979, 322. 
Y, ya entonces, el artículo 134 del mismo texto contenía también sobre la Provincia una fórmula semejante a la actual del artículo 141: "La Provincia es Entidad local determinada por la agrupación de Municipios (...)". El sentido de estos términos, a la luz del artículo 130 transcrito, no dejaba lugar a duda alguna.

La redacción del artículo 130-hoy 137-fue modificada definivamente por la Comisión de Asuntos Constitucionales del Congreso al aceptar una enmienda in voce de los socialistas (34). Pero en ningún momento del largo proceso constituyente, ni entonces ni en otra ocasión, se negó en intervención alguna que la Provincia se fundamente en la asociación, aunque legal, de Municipios, como se desprende de los términos-la agrupación de Municipios determina la existencia de la Entidad provincial-del definitivo artículo 141, 1, del texto constitucional.

\section{C) Precedentes de esta configuración de la Provincia}

Hay que recordar que ya en la Constitución de la Segunda República había dos preceptos muy similares a los actuales 137 y 141 de la vigente Constitución. Y por cierto que ambos formaban parte de un Título, el I entonces, que se intitulaba Organización nacional y que tantas significativas afinidades tiene con la denominación del actual Título VIII: "De la Organización Territorial del Estado».

El artículo $8 .^{\circ}$ del texto de 1931 decía:

«El Estado español, dentro de los limites irreductibles de su territorio actual, estara integrado por Municipios MANCOMUNADOS en Provincias y por las Regiones que se constituyan en régimen de autonomía."

Y el artículo 10 señalaba que:

"Las Provincias SE CONSTITUIRAN POR LOS MUNICIPIOS MANCOMUNADOS CONFORME A UNA LEY que determinará su régimen, sus funciones y la manera de elegir el órgano gestor de sus fines politicaadministrativos (...).»

(34) La enmienda fue defendida por el Diputado señor Peces-Barba, quien puntualizó que con ella se intentaba «una mejora que no es sustancial al texto de la Ponencia» (DS, 13 junio 1978, núm. 87, 3224). La enmienda, que no fue objeto de intervenciones en contra, fue aprobada por la totalidad de los miembros de la Comisión presente, salvo los dos votos en contra del Grupo de Alianza Popular, pero no parece que la oposición de este Grupo se basara en cuestión alguna relacionada con la naturaleza de las Provincias. 
Como subraya Boouera, "por primera vez (...) la idea de que la Provincia es una unión o comunidad de Municipios ocupa un lugar en el texto de una Constitución española»(35). Pero ya antes esta idea había inspirado a los autores del Estatuto provincial de 1925, en cuya exposición de motivos se lee que la Provincia, en cuanto es circunscripción de vida local, tiene su raíz y cimientos en los Municipios. "La idea de que la Provincia se cimenta sobre los Municipios, que éstos, y no los individuos, son quienes con su unión crean el substrato de su personalidad jurídica-ha señalado BoQuera-, ya no desaparece de nuestro Derecho" (36).

Es discutible y ha sido discutido si en el régimen político de las Leyes Fundamentales de Franco las Provincias eran en efecto Entidades intermunicipales o Entidades de primer grado, formadas directamente por la población provincial (37). Ciertamente la Base I de la Ley de 17 de julio de 1945 afirma claramente, a semejanza de

(35) Boquera Oliver, J. M. ${ }^{2}$ : La Provincia, cauce de representación política, Revista dE Estudios dE LA VIDA Local, núm. 156, noviembre-diciembre 1967, 811. Cfr. también Martín-Retortillo Baquer, S.: Las Corporaciones locales en el anteproyecto de Constitución, en «Estudios sobre el Proyecto de Constitución», CEC, Madrid, 1978, 184.

(36) Cfr. ob. cit. supra, ibidem. En este mismo trabajo se refiere Boouera a los antecedentes históricos que la concepción de la Provincia como agrupación intermunicipal encuentra en las Edades Media y Moderna en nuestro Derecho Público del Antiguo Régimen. Sobre la configuración de la Provincia en el Estatuto, vid. también González Mariñas, P.: La Provincia en España: apunte histórico-juridico, «RICA», número 3, 1977, 265, y Martín-Retortillo, S., y Argullol Murgadas, E.: Aproximación histórica al tema de la descentralización (1812-1931), en "Descentralización administrativa y Organización política», t. I, Ed. Alfaguara, Madrid, 1973 (autores: S. MarTínRetortillo y colaboradores), 345 y ss. Destacan estos autores que con el Estatuto Provincial, por primera vez de modo definitivo y pleno, se configure a la Provincia como entidad local, al margen de su consideración estricta como circunscripción de la Administración del Estado (pág. 345). En coherencia con la naturaleza que se reconocía a la Provincia, el Estatuto regulaba el sistema de Carta intermunicipal (arts. $6 .^{\circ}$ y ss.).

(37) Se opusieron a la naturaleza de la Provincia como agrupación de Municipios, García de EnTerría, E.: La Provincia en el régimen local, en "Problemas actuales del régimen local», IGO, Sevilla, 1958, 26, y Vallina Velarde, V. de la: La Pro. vincia, Entidad local, en España, Oviedo, 1964, 52 y ss.; Guaita, Aurelio: El concepto de Provincia, en "Problemas políticos de la vida local», V, Madrid, 1965, 201. 231, y en su libro División territorial y descentralización. IEAL, Madrid, 1975, 203. 258, especialmente en págs. 214-216, y García-Trevijano Fos, J. A.: Tratado de De. recho Administrativo, II-2, Ed. RDP, 2." ed., Madrid, 1971, 1072. En mi libro Los Consorcios en el Derecho español: análisis de su naturaleza jurídica, IEAL, Madrid, 1974, yo mismo seguí esta opinión doctrina (cfr. pág. 276).

La naturaleza de agrupación intermunicipal ha sido defendida por BoQUERA OLIVER, I. M.: La Provincia, cauce de representación política, REvisTA DE EsTUDIOS DE LA VIDA LOCAL, núm. 156, noviembre-diciembre 1967, 801-820, con sólidos argumentos. Cfr. también su Derecho Administrativo, 3. ${ }^{n}$ ed., IEAL, Madrid, 1979, 322.

Aún en los últimos años de vigencia de las Leyes Fundamentales subraya la nece. sidad de valorar el carácter de "agrupación de Municipios» en la caracterización de la Provincia, González Mariñas, P., en La Provincia en España..., cit., 266. 
la Constitución republicana, que «el Estado español se halla integrado por las Entidades naturales que constituyen los Municipios agrupados territorialmente en Provincias». Y la Base 38 de la misma Ley determina que "por cada partido judicial habrá un Diputado, que será elegido por compromisarios de los Ayuntamientos de la demarcación entre sus Alcaldes y Concejales». Los Diputados que podrían elegir las Corporaciones y las Entidades económicas, culturales o profesionales, así como las de la Organización Sindical, no podrían exceder de la mitad del de representantes de los partidos judiciales y tenían un carácter "complementario", según esa misma Base 38 de la Ley del 45 . Todo esto parece confirmar, como sostuvo BoQuera, el carácter ciertamente intermunicipal de la Provincia (38).

El texto articulado de la Ley de Régimen local introdujo, sin embargo, términos realmente confusos al referirse a la Provincia. Después de recogerse en el artículo $10^{\circ}$ lo que estableció la Base I antes citada de 1945 , el artículo $2 .^{\circ}$ afirmaría con poco acierto que "la Provincia es CIRCUNSCRIPCION determinada por la agrupación de Municipios, a la vez que división territorial de carácter unitario para el ejercicio de la competencia del Gobierno nacional». Estas expresiones se repetían, con resultados confusos, en el artículo 204.

La expresión del artículo $2 .^{\circ}$ de la Ley de Régimen local-que con su referencia al término de circunscripción tiene antecedentes en el Estatuto provincial de 1925 y en el proyecto constitucional de 1929-haría fortuna y sería en buena parte constitucionalizada en el artículo 45, II, de la Ley Orgánica del Estado de 1967 (39).

Evidentemente al utilizarse tal expresión podía entender el intérprete que lo que se quería decir al hablarse de «agrupación de $\mathrm{Mu}$ nicipios" no era sino agrupación de términos municipales o, si se prefiere, reunión totalmente pasiva de Municipios como. criterio de determinación de los límites territoriales de la circunscripción provincial (40). Claro que entonces resultaba difícil explicar cómo una circunscripción podía gozar de personalidad jurídica y en qué podía distinguirse circunscripción y división territorial. De ahí, en efecto, y habida cuenta además de la historia contemporánea de la Provin-

(38) Cfr. La Provincia, cauce..., cit., supra, 811 y ss.

(39) Critica también igualmente esta terminología, Boouera, loc. cit. supra, en nota anterior, y GuAITA, op. cit. supra, pág. 215 del libro División territorial y..., cit.

(40) Como puede verse en Guaita, op. cit. supra, ibidem y en mi libro Los Consorcios en el Derecho español..., 276. 
cia con anterioridad a la Dictadura de Primo de Rivera y la Segunda República, que surgiera la discrepancia en cuanto a la naturaleza de organización de primero o segundo grado de las Provincias.

En el anteproyecto de Constitución de 5 de enero de 1978 se mantenía también, por cierto, la impropia terminología de la Ley de Régimen local y de la Ley Orgánica del Estado al establecerse que:

«Las Provincias o, en su caso, las circunscripciones que los Estatutos de autonomía establezcan mediante la agrupación de Municipios, gozarán igualmente de personalidad jurídica (...)» (artículo 105, 2).

Acertadamente señalaba el profesor Juan Luis DE LA VALLINA VELARDE en una enmienda a ese artículo que presentó como Diputado, que la expresión "circunscripción» no resulta correcta para referirse a una Entidad dotada de personalidad jurídica. Esta expresión desaparecería en la nueva redacción dada al texto constitucional por la Ponencia de la Comisión constitucional del Congreso, que incorporó ya definitivamente el término Entidad para referirse a la Provincia.

Con claridad, sin embargo, había establecido anteriormente la Ley de Bases del Estatuto de Régimen local de 19 de noviembre de 1975 que «el Municipio y la Provincia constituyen las Entidades fundamentales de la Administración local» y que «las Provincias son Entidades determinadas por la agrupación de Municipios, a la vez que división territorial de la Administración del Estado». Aunque la misma Ley a renglón seguido decía también que «constituyen elementos integrantes, tanto del Municipio como de la Provincia, la población, el territorio y la organización» (base 1. ${ }^{2}$, apartados 1, 3 y 4). Como se sabe, esta Ley se derogó posteriormente en la mayor parte de sus bases, y, en consecuencia, esta base $1 .^{a}$ no llegó a tener vigencia efectiva. No es necesario entender, con todo, que aquella Ley quiso entonces apartarse expresamente de una concepción de la Provincia como Entidad de segundo grado, constituida por los Municipios como elemento personal. Cabía en efecto seguir entendiendo que el elemento personal de la Provincia estaría constituido por la población de la circunscripción provincial pero organizada por Municipios. Después de todo, esta interpretación podía utilizar además en su apoyo el principio esencial de las Leyes Fundamentales de la representación orgánica a través del Municipio, la Familia 
y el Sindicato, aunque la cuestión se prestaba desde luego a teorías diversas (41).

En cualquier caso, el sentido más inmediato de la expresión constitucional Entidad determinada por la agrupación de Municipios inclina a concluir que ciertamente la Provincia es, ahora, en nuestro vigente Ordenamiento constitucional, una Entidad local de segundo grado, cuyo elemento personal está constituido, en efecto, por los Municipios que agrupa. Y la aludida discusión doctrinal anterior a la actual Constitución hace aún más fundada esta conclusión, ya que cabe presumir en el constituyente la voluntad de excluir la interpretación contraria al haber utilizado precisamente los expresados términos.

\section{D) Consecuencias en cuanto al procedimiento electoral provincial}

Esta caracterización de la Provincia deberá reflejarse en la composición del órgano u órganos a quienes se encomiende su gobierno y dirección administrativa, a los cuales se refiere con terminología tradicional pero poco rigurosa el artículo 141, 2, de la Constitución al mencionar las Diputaciones y otras posibles Corporaciones de carácter representativo (42).

Lógicamente tales Corporaciones deberán ser representativas de los Municipios agrupados en las correspondientes Provincias. $\mathrm{Y}$ eso es lo que ocurre efectivamente hoy en mayor o menor medida con las Diputaciones provinciales de régimen común y con las Juntas Generales y Diputación foral de Alava. Según la vigente Ley de Elecciones locales de 17 de julio de 1978, los Diputados provinciales de las Provincias de régimen común se designan en una elección de segundo grado estrechamente vinculada a las elecciones municipales y con un procedimiento complejo que otorga un gran protagonismo a los partidos políticos y coaliciones electorales. Son conce-

(41) Cfr. LOE, art. 46, II, y Fuero de los Españoles, art. 10. Un comentario en García-Trevijano Fos, J. A.: Tratado..., 1I-2, cit., 1084-1085, y en mi libro Los Consorcios..., cit., 285 y ss., aunque ambas referencias son anteriores a la Ley de Bases de $1975 \mathrm{y}$, por tanto, no apuntan concretamente al problema interpretativo planteado en el texto.

(42) Aunque en rigor la Corporación-en sentido técnico jurídico-es la Provincia misma, es normal entre nosotros denominar Corporaciones a las Diputaciones y. en el ámbito municipal, a los Ayuntamientos. En este sentido, Corporaciones provinciales representativas pueden considerarse también las Juntas Generales y las Diputaciones vascas, el Parlamento y la Diputación forales de Navarra, las Mancomunidades interinsulares canarias o el Consejo interinsular balear. 
jales y entre concejales, en cada partido judicial, quienes proceden a la elección de los Diputados.

Las Juntas Generales de Alava-dice el artículo 2. del Real Decreto 122, de 26 de enero de 1979-son, conforme a su tradición histórica, el órgano de participación del pueblo alavés, a través de sus Municipios agrupados en Hermandades, en la administración y gobierno provincial. Se trata de una magnífica expresión concreta de lo que, a nuestro entender, exige básicamente la Constitución para todas las Provincias. Pues son efectivamente los concejales de los Ayuntamientos de cada una de las 18 Hermandades los que elegirán a los Procuradores que representarán a cada Hermandad en las Juntas Generales, siguiendo, conforme al artículo 3. - apartados 4 a 6-, un procedimiento similar al aplicado para la elección de los Diputados provinciales por los concejales de los Ayuntamientos de cada partido judicial en las Provincias de régimen común. Los Diputados de la Diputación Foral, por su parte, se eligen por Cuadrillas-que, en número de siete, agrupan a las distintas Hermandades-por los partidos políticos, coaliciones o agrupaciones electorales representados en las Juntas Generales, en función del número de Procuradores que cada uno de ellos tenga por cada Cuadrilla. En definitiva, aun complicado notablemente el sistema por la interferencia quizás excesiva de las formaciones políticas, son en realidad los representantes municipales quienes desde las Juntas Generales y por Cuadrillas designan a los 16 miembros de la Diputación Foral, que es así también un órgano de representación municipal. El régimen orgánico de la Provincia de Alava resulta, en suma, el más coherente con la naturaleza intermunicipal de la Provincia, el más participativo para todos los Municipios de ella, aun contando con la considerable mediatización que los partidos políticos han impuesto en todo el actual régimen electoral.

En las páginas siguientes nos detendremos brevemente a comentar las diferencias que en este sentido presentan los actuales regímenes provinciales del Señorío de Vizcaya y las Provincias de Guipúzcoa y Navarra, así como los de los Territorios insulares canario y balear. Pero antes de entrar en ese análisis, conviene que concluyamos estas consideraciones sobre las consecuencias derivadas de la naturaleza intermunicipal de las Provincias en la actual Constitución. El hecho de que, a diferencia de lo que establece el artículo 140 en cuanto a los Municipios o el artículo 152,1 en cuanto a las Comunidades Autónomas, el artículo 141 del texto constitucional 
nada indique acerca del procedimiento de elección de los miembros del órgano u órganos de gobierno de la Provincia, salvo la exigencia general de su necesario carácter representativo (apartado 2 ), puede verdaderamente interpretarse como un signo más de que la Constitución institucionaliza a las Provincias como auténticas agrupaciones legales de Municipios. Serán los Municipios, por tanto, los que deberán encontrarse representados en la Corporación provincial. Serán ellos los que designen o elijan a sus miembros. La ley podrá atribuir esa función o derecho electoral a los Ayuntamientos o podrá atribuírselo directamente al cuerpo electoral de cada Municipio (43). En cualquier caso el sistema electoral deberá evitar la reducción excesiva del número de circunscripciones electorales, pues ello po-

(43) La representación municipal en la Provincia es evidentemente una representación de intereses, como señalaba García-Trevijano en el Tratado..., II-2, citado, 1085, y no hará ninguna falta que cada representante de Municipio o grupo de Municipios consulte sus intervenciones y votos a las Entidades municipales correspondientes, a semejanza de como tampoco tienen esta obligación los Senadores de nuestro actual Senado en relación con las Provincias o con las Comunidades Autónomas a que representen en virtud de lo establecido en el artículo 69 de la Constitución. Lo que no impide, sin embargo, que puedan establecerse-y aun sean quizá convenientes-cauces de comunicación y aun de consulta formal entre el representante y los repreesntantes, sin perjuicio de que pueda a la vez exigirse, como para los miem. bros de las Cortes Generales, que no estén ligados por mandato imperativo alguno. $\mathrm{Y}$ es que a la postre la representación política, tal y como se entiende generalmente en la actualidad, excluye ese tipo de dependencias tanto si se representa a toda la comunidad para la que se establece el órgano correspondiente como si àdemás o solamente se representa a una parte de ella acotada territorialmente por constituir por sí una comunidad inferior específica o un grupo de ellas.

Por otra parte, ya el Estatuto provincial de 1925 afirmó en la exposición de motivos: "... si los Municipios son depositarios de la soberanía provincial, las Diputaciones deberían componerse únicamente de mandatarios de los Ayuntamientos. Pero esto sería ir demasiado lejos, aunque no haya por qué rechazar la hipótesis, perfectamente realizable en régimen de Carta intermunicipal. Es evidente, en efecto, que Municipio y Ayuntamiento son cosas distintas, y puede entenderse que el primero irá a la Diputación por medio de los Diputados directos, ya que el Municipio es suma de ciudadanos, y que el segundo en cambio irá por medio de los corporativos, que serán individuos salidos de su seno... La representación corporativa (de los Ayuntamientos), en fin, no persigue designio antidemocrático ni surge de clases sociales o intereses privados, sino de otras Corporaciones de índole local democráticamente engendradas». Por cierto que los Diputados directos eran elegidos, bajo el Estatuto provincial, en distrito único que abarcaba toda la Provincia, lo cual, aunque respondiese a razones muy atendibles que la misma exposición de motivos del Estatuto exponía, hay que reconocer que no era muy coherente con la fundamentación que, como hemos visto, quería darse a esos Diputados, como representantes de los Municipios elegidos por sus respectivos ciudadanos.

Cfr. el comentario crítico al texto citado de la exposición de motivos del Estatuto de 1925, hecho por Boouera Oliver, J. M.': La Provincia, cauce..., cit., 814 y ss. Efectivamente, la exposición de motivos no se expresó en términos precisos, ya que en realidad el Municipio tanto iría a la Diputación mediante representantes elegidos directamente por los ciudadanos-que como población municipal son el órgano supremo de aquél en el acto de emitir el sufragio-como mediante los que eligiera su Ayuntamiento, su órgano institucional superior de gobierno y administración. 
dría equivaler a una adulteración completa de los principios de la representatividad territorial-municipal en este caso-. El sistema más coherente con los principios incluiría una primera fase de elección de uno o más compromisarios por Municipio, teniendo racionalmente en cuenta la diversidad cuantitativa de población, y una segunda fase en la que los compromisarios de los distintos Municipios de cada demarcación o circunscripción intermedia elegirían definitivamente a los representantes asignados a la misma en el órgano supremo provincial. Los compromisarios podrían ser designados por los Ayuntamientos respectivos o directamente por la población de cada Municipio (44).

Pues hablarse, en resumen, de un auténtico derecho de los Municipios a ser tenidos en cuenta como elemento determinante en la composición de los órganos de gobierno y administración de la Provincia-al menos del supremo-. Un derecho que, al ser la Provincia una Entidad constitucionalmente necesaria, pertenece a todos los Municipios españoles, cualquiera que sea la zona del territorio nacional en que se encuentren. Salvo las excepciones previstas en la Constitución misma, los Municipios, además del área de competencias propias que se les encomiende en régimen de autonomía, deben constituir la base del gobierno y administración de finalidades o intereses supramunicipales de ámbito provincial, o, lo que es igual, el ejercicio de las competencias que la legislación local encomiende a las Provincias debe atribuirse a órganos compuestos por representantes municipales. Pienso, por lo demás, que este derecho municipal es un derecho constitucional y como tal plenamente garantizable en su caso por el Tribunal Constitucional.

(44) Hay que hacer hincapié en la dudosa coherencia de todo sistema electoral directo organizado sobre circunscripciones plurimunicipales. Estas son cicrtamente admisibles en un sistema de elección en segundo grado que mantenga una primera votación de compromisarios por Municipio (sean concejales o compromisarios ad hoc distintos de los miembros de los Ayuntamientos), pero no deja de ofrecer serias dudas de constitucionalidad el constituir circunscripciones de ese tipo, plurimunicipal, para proceder directamente en cada una de ellas a la elección de los niembros del órgano u órganos del gobierno provincial. Incluso el sistema adoptado en la Ley de Elecciones locales con carácter general para las Diputaciones de régimen común-aplicado con adaptaciones a Alava-no deja de ofrecer reparos, a pesar de que no prescinde-al menos formalmente-de las repreesntaciones concejiles.

Habría, en suma, que aplicar aquí los criterios que rigen la formación de las llamadas Cámaras de Estados en los Estados federales, puesto que la ratio es la misma. Cfr. al respecto Burdeau, G.: Traité de Science politique. 2.2 ed., II. L. G. D. J., París, 1967, 505 y ss., y el reciente trabajo de Ramón PUNSET: El concepto de representación territorial en la Constitución española de 1978, en «Revista del Departamento de Derecho Político» (UNED), núm. 7, otoño 1980, 105 y ss. 


\section{E) Análisis del tema en el régimen foral de Navarra "amejorado» en 1979.}

Parece conveniente a este respecto analizar el «amejoramiento» del Fuero navarro operado por Real Decreto núm. 121, de 26 de enero de 1979.

Y lo primero que resulta obligado destacar es la discutible constitucionalidad del camino seguido para llevar a cabo esa reforma institucional.

El «amejoramiento» del régimen foral establecido en la Ley Paccionada de 16 de agosto de 1841 se ha efectuado por Real Decreto, lo que en modo alguno parece compatible con una correcta aplicación de los principios y normas constitucionales en materia de fuentes del ordenamiento.

Y no puede servir de justificación el que el propio Decreto alegue basarse en una autorización conferida al Gobierno por el Real Decreto-ley núm. 1, de 4 de enero de 1978, en su disposición final segunda. Dicha autorización lo era "para modificar la composición y atribuciones del Consejo Foral de Navarra, de acuerdo con su Diputación Foral", y apoyándose en ella el Gobierno-aun de acuerdo al parecer con la Diputación Foral-ha transformado por completo ese Consejo, convirtiéndolo en el Parlamento Foral, al cual se le han atribuido competencias que antes pertenecían a la Diputación Foral, conforme a la Ley Paccionada. Y es claro que el rango de ley propio de la Ley Paccionada exige por parte del Estado la intervención plena de las Cortes para cualquier modificación de la misma, sin que por Decreto-ley pueda operarse deslegalización alguna al respecto. El Gobierno no puede en forma alguna autosubrogarse en el lugar de las Cortes y modificar una asignación de competencias establecida por una Ley por vía de simple Decreto. Podría, como mucho, hacer esa modificación mediante Decreto-ley directamente, guardando los debidos condicionamientos impuestos por el ordenamiento constitucional a los Decretos-leyes, pero nunca mediante Decreto, mientras las Cortes no deslegalizaran esa materia previamente (45).

(45) Sobre la deslegalización por Decreto-ley, su inconstitucionalidad bajo las Leyes Fundamentales y bajo la nueva Constitución y el problema de hacer efectiva tal inconstitucionalidad, me remito a lo que he dejado escrito en Reserva y autorreserva legales en materia de organización de la Administración del Estado, «RAP», núm. 92, mayoagosto 1980.

El Real Decreto-ley de 4 de noviembre de 1925, en su Base XII condicionó algunas 
El Decreto citado de "amejoramiento" invoca también en la exposición de motivos como título habilitante el artículo 36 de la Ley de Elecciones Locales de 17 de julio de 1978, en virtud del cual la aplicación de esta Ley "en Navarra se realizará conforme a lo que dispone la Ley Paccionada de 16 de agosto de 1841, con las modificaciones que puedan introducirse de acuerdo con la Diputación Foral». Y ciertamente el «amejoramiento» ha incluido algunas modificaciones importantes del régimen tradicional de designación o elección de los Diputados forales, modificando en consecuencia la Ley Paccionada. Y ello por Decreto. Aquí la deslegalización vendría operada por ley de las mismas Cortes, con lo que habría que aceptar su validez, a no ser que se trate de una materia de reserva de ley, excluida por tanto de toda posibilidad de deslegalización. Pero se observará en primer lugar que el texto citado del artículo 36 de la Ley de Elecciones Locales invocado no transfiere al Gobierno potestad ni competencia alguna, limitándose a indicar que podrán introducirse-por quien corresponda, habrá que entender implícitamente-modificaciones de la Ley Paccionada de acuerdo con la Diputación Foral. No puede hablarse, por ende, en rigor de que aquí se ha producido la presunta deslegalización necesaria habilitante de la regulación electoral contenida en el Decreto $121 / 79$. Pero es que además, en el supuesto de que tal deslegalización se hubiera llegado a producir, la Constitución, publicada un mes antes de este Decreto, la habria hecho decaer plenamente en sus efectos, ya que reserva a la ley el régimen electoral (46). De modo

de las competencias de la Diputación Foral, al establecer la necesaria aprobación del Consejo Administrativo de Navarra en ciertos supuestos. Ello supuso cierta modificación de la Ley Paccionada de 1841. Vid. Gómez Antón, F.: El Consejo Foral Administrativo de Navarra, Ed. Rialp, Madrid, 1962, especialmente 47 y ss.; Gallego ANARITARTE, A.: La adaptación del Estatuto municipal de 1924 a las Provincias Vasco-Navarras. en «Estudios conmemorativos del Cincuentenario del Estatuto municipal». IEAL, Madrid, 1975, 685-706, y Cosculluela Montaner, L. M., y MuÑoz Machado, S.: Las Elecciones locales, Ed. Abella, Madrid, 1979, 347 y ss. El Decreto-ley de 4 de enero de 1978 podría haber modificado directamente el Consejo Foral Administrativo-previo acuerdo con la Diputación navarra-, por razones de urgencia, pero no podía deslegalizar esa materia.

(46) Cfr. artículos 23 y 81,1, y artículo 82, 1, de la Constitución, en relación con el artículo $9 .^{\circ}$ de la Ley de 16 de agosto de 1841, que organiza la Administración General de Navarra. Y el artículo 86 , relativo a los decretos-leyes, prohíbe que ćstos se refieran al Derecho electoral general. Si la autorización del artículo $36 \mathrm{de}$ la Ley de Elecciones locales se hubiera entendido como simple remisión normativa para aplicar estrictamente a Navarra los criterios electorales establecidos en ella con carácter general para la elección a las Diputaciones, y el Decreto $121 / 79$ se hubiera mantenido dentro de esos criterios, no habría probablemente nada que objetar. Pero no ha sido éste ni mucho menos el alcance de la reforma. 
que también en este aspecto el «amejoramiento» del Fuero navarro operado por el Real Decreto 121/79 parece efectuado por una disposición de rango constitucionalmente insuficiente $\mathrm{y}$, por tanto, por un órgano sin competencia para ello, lo que la convierte en inconstitucional y nula.

Por lo demás, la autorización conferida al Gobierno en el Real Decreto-ley 2, asimismo de 4 de enero de 1978, para determinar, de acuerdo con la Diputación Foral, el órgano foral competente a quien habría de corresponder la decisión de incorporarse o no Navarra al País Vasco, a que se refiere la transitoria primera del Decreto-ley $1 / 78$, para ser válida no podía referirse a órganos nuevos cuya constitución implicara modificación de normas con rango de ley, por lo que tampoco puede prestar base constitucional suficiente al Decreto $121 / 79$.

Pero, al margen de estos problemas-sin duda, serios-de constitucionalidad formal, podemos observar que el «amejoramiento» foral ha suprimido prácticamente por entero la tradicional vinculación de la elección de los Diputados forales-y lo mismo en cuanto a la elección al Parlamento foral-con los Municipios agrupados en las históricas Merindades.

En el nuevo sistema es el pueblo mismo del conjunto de los $\mathrm{Mu}$ nicipios integrados en cada Merindad el que directamente vota a los cinco o más miembros del Parlamento y al Diputado o Diputados que correspondan por cada Merindad. El principio de que son los Municipios quienes-según la actual Constitución española-componen con su agrupación la Provincia y quienes por tanto deben estar representados en sus organismos de gobierno y administración queda muy desdibujado y casi prácticamente eliminado, lo que tendría que llevar a la conclusión de la inconstitucionalidad, también por razón de la materia, del "amejoramiento" efectuado. Pero se admita o no su constitucionalidad, lo que es evidente es que este sistema entraña una efectiva reducción de la participación de los pequeños Municipios de las Merindades en el seno de los órganos provinciales, al disminuir notablemente el grado de su posibilidad de influencia en la elección correspondiente, que habrá de realizarse ahora sobre listas únicas para cada Merindad, convertida de este modo en simple distrito o circunscripción electoral.

Hay con todo algún detalle en el Decreto 121/79 que descubre aún cierta conexión de los miembros del Parlamento y de la Dipu- 
tación Foral con los Municipios, si bien se trata de algo de reducida significación y que puede encontrar incluso otras justificaciones. Me refiero a la indicación contenida en el artículo $2 .^{\circ}$ sobre las causas de inelegibilidad e incompatibilidad de los artículos $7 .^{\circ}$, 1 , y $9 .^{\circ}, 1$, de la Ley de Elecciones Locales, que afirma deben referirse, en el caso de las elecciones al Parlamento y Diputación de Navarra, al Municipio en el que el candidato tenga su residencia, en lugar de referirse a toda la Provincia, como podría justificar el hecho de que se trata de elecciones a órganos provinciales (47).

\section{F) La cuestión en las Provincias Vascongadas}

El sistema implantado en Navarra es en realidad muy semejante al establecido para las Provincias vascas de Guipúzcoa y Señorío de Vizcaya. Los Reales Decretos 123 y 124, que regulan la organización y funcionamiento de las Juntas Generales y Diputaciones Forales de ambas Provincias, son del mismo día 26 de enero de 1979, en que fue dictado el Real Decreto 121/79, relativo a Navarra.

Ambos Reales Decretos reorganizadores de las instituciones provinciales de Vizcaya y Guipúzcoa han sido dictados asimismo en uso de una presunta autorización otorgada al Gobierno por la disposición final primera del Real Decreto-ley 1/1978, de 4 de enero, que creó el Consejo General del País Vasco. Dicha autorización habilitaba, en efecto, al Gobierno, "previa consulta al Consejo General del País Vasco, para reformar antes de las elecciones generales municipales el Real Decreto-ley 13/1977, de 4 de marzo, por el que se restauran las Juntas Generales de Guipúzcoa y Vizcaya, en cuanto se refiere a la composición y forma de elección de sus miembros». Hay que insistir de nuevo aquí en que por Decreto-ley no se puede operar una deslegalización de esta índole-ni de ninguna otra-, al igual que lo señalábamos a propósito del Decreto $121 / 79$ sobre Navarra; esa autorización era y es anticonstitucional y por consiguiente los Decretos de que ahora tratamos resultan formalmente inválidos (48).

(47) A título meramente ilustrativo anotemos que el Tribunal Supremo. en Sentencia de 13 de junio de 1979 (Sala 4. ${ }^{2}$ ), ponente Excmo. Sr. D. J. Gabaldón López (Ayuntamiento de Estella v. Diputación Foral de Navarra), Aranzadi, R. 4749, rcconoció legitimación activa a un Ayuntamiento en un problema relativo a la composición de la Diputación de Navarra.

(48) Pueden reiterarse los argumentos apuntados a propósito del «amejoramiento» navarro. Tampoco el artículo 136 de la Ley de Elecciones locales, siempre invocado al comienzo de las exposiciones de motivos de los Decretos correspondientes, 
Por cierto que el Real Decreto-ley de 1977 que restauró las Juntas Generales guipuzcoanas y vizcaínas era mucho más consecuente con la naturaleza intermunicipal de la Provincia-tanto histórica, como bajo la actual Constitución-cuando expresamente señalaba por ejemplo en el artículo $2 .^{\circ}, 1$, que las Juntas Generales «son, respectivamente, el órgano de participación de los pueblos guipuzcoano y vizcaino, A TRAVES DE SUS MUNICIPIOS, en el gobierno provincial», precepto que, por lo demás, hay que considerar plenamente vigente hoy, encuadrando toda la regulación actual de las correspondientes instituciones, ya que nada de lo establecido en los Decretos 123 y 124 de 1979 se opone en rigor a ello. Pero, en la regulación de 1977, el modo de composición y designación de Juntas y Diputaciones era mucho más claramente consecuente con ese principio de representación municipal; las Juntas se integraban "por representantes de todos sus Municipios" (artículo 2. $.^{\circ}, 2$, de ambos Decretos), y las Diputaciones se elegían por las respectivas Juntas Generales, siendo electores los Procuradores (en Guipúzcoa) y los Apoderados (en Vizcaya) de cada una de las circunscripciones o comarcas en que a tales efectos se dividen las dos Provincias, de tal manera que los de cada comarca o circunscripción elegirían al Diputado o Diputados que les correspondiese en su representación.

No parece justificado que se haya abandonado este sistema electoral, adoptándose en 1979 otro que verdaderamente roza los límites de lo inadmisible desde un punto de vista estrictamente constitucional. Ha habido una vez más-como en Navarra-quizás excesivo mimetismo con respecto al sistema electoral que se estima adecuado para el Legislativo estatal. o supervaloración del principio del sufragio individual, oscureciéndose tal vez las razones aue precisamente con vistas a las funciones administrativas de las Provin-

puede prestar base a estos Decretos, que han prescindido en la elección de las Iuntas Generales, y en consecuencia en la de sus Dinutaciones Forales, de los concejales, a diferencia de lo aue establece la Lev de Elecciones locales para las Diputaciones de régimen común. Si el artículo 36 contenía una simple remisión normativa para la anlicación de los criterios adoptados por dicha Ley en materia de elecciones provinciales. lo cierto es que el Gobierno-aun de acuerdo con el Conseio General del País Vasco-lo ha entendido en la práctica como una auténtica cláusula de deslegalización, considerándose habilitado para reformar la composición $v$ el sistema electoral de Iuntas y Dinutaciones con arreṣlo a nuevos criterios. Tan sólo parece haberse tenido en cuenta cierta analogía con lo dispuesto para las Diputaciones de régimen común en punto a la designación de los Dinutados forales con hase en los resultados electorales para las Juntas Generales-en lugar de los prorlucidos en las elecciones municipales-. Efectivamente se ha dado también aquí amplia entrada a las organizaciones políticas, que asumen un protagonismo similarmente excesivo. Pero esta analofía no creo sea suficiente para legitimar formalmente toda la operación reformadora llevada a cabo. 
cias abonan la conveniencia de primar el voto de esas minorías menos poderosas que son de ordinario quienes habitan en las zonas periféricas o más rurales, garantizándolas así una presencia mínima en la gestión de las cuestiones provinciales que evite su definitiva marginación y olvido.

Por lo que se refiere a la Provincia de Alava, ya hemos dejado expuesto anteriormente cómo se trata de un régimen ciertamente acorde y consecuente con las exigencias constitucionales sobre la Provincia. Anotemos aquí solamente, a modo de complemento de lo ya expuesto, que sus Juntas Generales fueron restablecidas por Real Decreto 1611, de 2 de junio de 1977, en cumplimiento del encargo efectuado al Gobierno por la disposición final segunda del Decreto-ley 13, de 4 de marzo de 1977. Y entonces a cada Municipio alavés se le reconoció el derecho a elegir al menos un Procurador (artículo 2..$^{\circ}$ ), debiendo hacerse la elección por el pleno del Ayuntamiento correspondiente, el cual podía designar a un vecino no concejal. Los Diputados forales eran elegidos por las Juntas Generales, designándose una parte entre miembros de Corporaciones locales y un número equivalente a la mitad de los anteriores entre vecinos alaveses que no formasen parte de aquéllas. Estos últimos eran designados por la totalidad de los Procuradores de las Juntas; los primeros, en cambio, agrupándose los Procuradores por circunscripciones territoriales. Es una lástima que la reforma de 1979 haya reducido la palmaria transparencia que este sistema mostraba del verdadero carácter intermunicipal de la Provincia alavesa.

Hay que indicar, finalmente, para concluir este breve análisis del régimen de las Provincias Vascongadas, que el Estatuto de Autonomía del País Vasco ha establecido en el artículo 37, 5, poco afortunadamente, que "para la elección de los órganos representativos de los Territorios Históricos-las Provincias-se atenderá a criterios de sufragio universal, libre, DIRECTO, secreto $y$ de representación proporcional, con circunscripciones electorales que procuren una representación adecuada de todas las zonas de cada territorio". Es decir, sienta un criterio contrario a la elección de segundo grado, pero admite que la elección se efectúe por Municipios o por Municipios agrupados en Cuadrillas y Hermandades (Alava) o Comarcas (Vizcaya y Guipúzcoa). Teniendo en cuenta que los órganos máximamente representativos en esas Provincias son las Juntas Generales, cabe perfectamente dentro de la fórmula del artículo 37, 5, del Estatuto, que el sistema electoral siga tomando como base el $\mathrm{Mu}$ - 
nicipio, volviendo incluso al régimen puro de 1977. Se ha cometido, sin embargo, el error de emplear ese término vago y genérico de "zonas de cada territorio", en lugar de hablarse propiamente, en plena conformidad con la Constitución, de los Municipios. Y por zonas del territorio pudiera entenderse más bien esas otras circunscripciones que agrupan a los Municipios en cada Provincia a niveles comarcales.

\section{G) Régimen especial de las Provincias insulares}

Los territorios insulares de España no son una excepción en cuanto al régimen provincial en sus caracteres esenciales: también en ellos deben existir las correspondientes Entidades provinciales como agrupaciones de Municipios.

Su única especialidad constitucional en punto a la Administración local es que, como dispone el artículo 141, 4, de nuestra carta fundamental, "en los archipiélagos, las islas tendrán además su administración propia en forma de Cabildos o Consejos». Es decir, que además de lo dispuesto en el mismo artículo 141 sobre las Provincias y sobre la posibilidad de crearse agrupaciones de Municipios distintas o diferentes de ellas, es de derecho constitucional necesario que las islas tengan su Administración local propia. El además pone bien de relieve que la institucionalización de las Administraciones insulares no debe llevar a la supresión de las Provincias sobre los territorios de los archipiélagos ni a la pérdida de su carácter constitucional de agrupaciones de Municipios. Lo cual no impide, sin embargo, aceptar que la interposición de un nivel insular de Administración local entre el nivel municipal y el provincial haya de repercutir por lo pronto en la esfera de competencias que deban asignarse en los archipiélagos a la Entidad provincial y a las Entidades municipales. En cuanto a la primera porque, tratándose de un nivel supramunicipal, parece razonable que algunas de las competencias encomendadas a las Provincias de régimen común, por afectar a intereses supramunicipales comarcalizables- «insularizables»-, se atribuyan a las Entidades insulares, habida cuenta, además, de la estructura territorial característica de los archipiélagos. $\mathrm{Y}$ en cuanto a las segundas porque la institucionalización de la Entidad insular puede aconsejar en más de un caso que sea ella quien asuma buena parte de las competencias que de otra manera corresponderían a Municipios de insuficientes medios y dimensio- 
nes, sin perjuicio de que conserven su existencia y algunos cometidos (49).

Por lo demás, cara a la composición interna del órgano de gobierno y administración provincial, la existencia de las Entidades insulares podría aconsejar ciertamente que la elección de sus miembros se hiciera a partir de los Cabildos o Consejos insulares, siempre y cuando a su vez éstos procedieran de las representaciones concejiles o de elecciones por Municipios. Los órganos de las Entidades insulares cumplirían así la función agrupadora que de otra forma cumplen los partidos judiciales en las Provincias de régimen común y el sistema de designación de los Consejeros o miembros del órgano de gobierno de la Provincia no dejaría en consecuencia de reflejar la naturaleza de agrupación de Municipios que la Provincia ostenta por imperativo constitucional. Las Provincias insulares deben ser tan agrupación de Municipios como las demás de la Nación, aunque puedan ser también a la vez agrupación de islas, siendo éstas así mismo, en su nivel, agrupaciones de los Municipios de sus respectivos territorios.

La legislación local que arranca de 1945 respetó siempre el régimen provincial especial de las Islas Canarias, con sus Cabildos insulares y sus Mancomunidades interinsulares, una para cada una de las dos Provincias de Santa Cruz de Tenerife y Las Palmas. El artículo 423 del Reglamento de Organización, Funcionamiento y Régimen jurídico de las Corporaciones locales de 17 de mayo de 1952-que reiteraba lo dispuesto por el artículo 189 del Estatuto Provincial de Calvo Sotelo en su redacción de 1928 (50)-, establece que los Cabildos insulares tienen las funciones, derechos y obligaciones de las Diputaciones provinciales, salvo, naturalmente, las que el artículo 428 atribuye a las Mancomunidades interinsulares. En realidad, por tanto, la organización provincial se diversifica en régimen de descentralización, convirtiéndose los Cabildos en base del sistema. Los Consejeros de los Cabildos se elegían por el mismo sistema que los Diputados provinciales en las Provincias de régimen

(49) En la línea que apuntaba la Ley de Bases del Estatuto de Régimen local de 19-XI-75 al institucionalizar en su Base X las Entidades municipales de ámbito comarcal o, incluso, en la Base XI, articulada por el Real Decreto 3046, de 6 de octubre de 1977 (arts. 1. al 9.'), donde se regulan las Agrupaciones forzosas de $\mathrm{Mu}$ nicipios con población inferior a los 5.000 habitantes.

(50) El Título VI del Libro I del Estatuto provincial de 1925 fue objeto de una nueva redacción por Real Decreto-ley de 8 de mayo de 1928, el cual dividió en dos Provincias el Archipiélago Canario y estableció las dos Mancomunidades interinsulares. 
común, con lo que al menos la mitad tenían un claro carácter de representantes de los Municipios (cfr. artículo 228, 5, de la Ley de Régimen local de 1950-1955). La Ley de Elecciones Locales de 1978, en su artículo 37, ha modificado el sistema, introduciendo un procedimiento de algún parecido con el que se ha adoptado para la elección del Parlamento Foral navarro o las Juntas Generales de Guipúzcoa y Vizcaya:

"En cada Cabildo insular canario se elegirán por sufragio universal, directo y secreto, y en una urna distinta a la destinada a la votación para Concejales, tantos Consejeros como a continuación se determina» (de once a veintiuno, según el número de habitantes residentes).

Cada isla es un distrito electoral único, aunque se prevé un complicado sistema cuando en una isla haya más de un partido judicial (artículo 37, 3) (51).

Los Cabildos eligen luego, como establece el Reglamento de Organización, Funcionamiento y Régimen jurídico de las Corporaciones locales (52), a sus representantes en las Mancomunidades interinsulares.

Lo más notorio es que con la nueva Ley de Elecciones Locales se ha suprimido toda base municipal en la elección de los Cabildos. La constitucionalidad material de este sistema, adoptado en 19781979, tanto bajo las Leyes Fundamentales derogadas como bajo la nueva Constitución, resulta así más que dudosa, a semejanza de cuanto ha quedado dicho sobre Navarra, Guipúzcoa y Vizcaya.

Análogamente a cuanto apuntábamos a propósito de las reformas implantadas en estas tres Provincias forales, es por lo menos discutible que pueda aceptarse la constitucionalidad del procedimiento electoral establecido, sobre la base de afirmar que son los cuerpos electorales de los distintos Municipios, aun reunidos en un solo distrito electoral-en este caso de dimensión insular-, quienes eligen a sus representantes en los correspondientes Cabildos y, a través de éstos, a los que les representen en la Mancomunidad interinsular. Lo cierto es que la representatividad municipal de los Conseje-

(51) Como observan Cosculluela y MuÑoz Machado, la isla como distrito electoral no es en rigor una designación enteramente geográfica, sino administrativa, debiendo entenderse que se integra por todo el ámbito territorial del Cabildo, lo que supone que alguna de las siete islas canarias comprende también otras islas o islotes administrativamente integrados en ellas (cfr. Las Elecciones locales..., cit., 357). El Real Decreto 118, de 26 de enero de 1979, regula las elecciones a los Cabildos canarios, desarrollando la Ley de Elecciones locales.

(52) Cfr. Ley de Elecciones locales, artículo 38, y Reglamento de Organización, Funcionamiento y Régimen Jurídico de las Corporaciones locales, artículo 427. 
ros de los Cabildos y de las Mancomunidades no aparece ahora por ningún lado y que la elección parece montada sobre criterios de pura representatividad política, estrictamente individual. En suma, el mismo problema que observábamos en el actual sistema de elección por Merindades de los Parlamentarios y Diputados forales navarros, o bien-aun cuando respecto a estas Provincias siga vigente formalmente el artículo $2 .^{\circ}, 1$, del Decreto-ley 13/1977, con su afirmación de la intermunicipalidad de sus Juntas Generales-en la elección de los Apoderados de las Juntas de Vizcaya por cada Comarca o de los Procuradores de las de Guipúzcoa por cada una de sus respectivas Comarcas.

En el archipiélago balear ha sido el Real Decreto-ley núm. 18, de 13 de junio de 1978, ya citado en estas páginas, el que ha creado un régimen especial para la Provincia de Baleares, hasta entonces inexistente. Su artículo 3..$^{\circ}$ instituye el Consejo General Interinsular, y el $4 .^{\circ}$ los Consejos insulares de Mallorca, Menorca e Ibiza-Formentera, cuyas competencias quedan establecidas respectivamente en los artículos $5 .^{\circ}$ y $7 .^{\circ}$. Un mes más tarde a su creación, la Ley de Elecciones Locales, a la que hace diversas referencias anticipadas el Decreto-ley antes mencionado, en el artículo 39, establece normas sobre la composición y elección de esos Consejos, añadiendo, como ya sabemos, el artículo 40, que la Diputación sería sustituida por ellos en sus funciones. Las normas electorales son como las que hemos visto para el archipiélago canario y merecen el mismo comentario (53).

\section{LAS COMUNIDADES AUTONOMAS UNIPROVINCIALES: FUNDAMENTO Y JUSTIFICACION}

\section{SU FUNDAMENTO CONSTITUCIONAL}

Como ya dijimos en la Introducción, la Constitución de 1978 admite tres supuestos diferentes en los que una sola Provincia puede acceder a su autogobierno constituyéndose en Comunidad Autóno$m a$, según los propios términos del artículo 143, 1. Esos tres supuestos son los siguientes:

(53) Cfr. Real Decreto 119, de 26 de enero de 1979, que regula las elecciones a los Consejos insulares y al Consejo interinsular de las Islas Baleares, desarrollando el artículo 39 de la Ley de Elecciones locales. 
1. El de "Provincias con entidad regional histórica» (artículo 141,1$)$, que pueden constituirse en Comunidades Autónomas por los procedimientos generales y comunes regulados en la misma Constitución.

2. $\quad$ El de Provincias que constituyan a la vez un «territorio insular», en cuyo caso habría que situar en realidad solamente al archipiélago balear, ya que el territorio canario está dividido en dos Provincias. Este supuesto, contemplado implícitamente en el mismo artículo 141, 1, permite también la constitución de la Comunidad Autónoma por los procedimientos generales.

3. El de las demás Provincias que por motivos de interés nacional sean autorizadas expresamente por las Cortes Generales, mediante una ley orgánica, a constituirse como tales en Comunidades Autónomas [artículo 144, a)]. Una vez obtenida esa autorización especial de las Cortes, pueden constituirse en Comunidades Autónomas por los procedimientos generales de la Constitución.

Este supuesto se referirá, en definitiva, al caso de aquellas Provincias que sin poder probar una "entidad regional histórica», ni ser territorios insulares, se consideran a sí mismas como constitutivas en la actualidad de auténticas Regiones con derecho a la autonomía, en virtud del artículo 2. ${ }^{\circ}$ de la Constitución. Naturalmente, tal «sustancia regional» tendrá que ser demostrada ante las Cortes, quienes se reservan la potestad de reconocer esa condición mediante ley orgánica, sin perjuicio, naturalmente, del ulterior control del Tribunal Constitucional, que, por lo demás, no podrá ir mucho más allá de los aspectos puramente formales, ya que la Constitución no proporciona los criterios materiales que deben tomarse en consideración por las Cortes para proceder a la autorización a que nos estamos refiriendo, siendo en consecuencia amplísima la discrecionalidad de la potestad de que se trata. Es evidente, por otro lado, que las Cortes tendrán que tomar tal decisión por motivos de interés nacional, como expresamente indica este artículo 144, pero no parece que esta previsión ad hoc del texto constitucional añada un elemento teleológico que no deba estar presente con carácter general en la actividad del Legislativo nacional (54).

(54) Una crítica a la distinción de regímenes establecida en la Constitución para las Regiones con o sin entidad regional histórica, en la intervención al Senado, Comisión de Constitución, el 12 de septiembre de 1978 del Senador HuERTA ARGenta, del Grupo Parlamentario Progresistas y Socialistas Independientes (DS, núm. 53, 2542 y ss.).

Para un análisis del artículo 144, vid. Al.varez Conde, E.: Los titulares de la iniciativa del proceso autonómico, en esta Revista, núm. 202, abril-junio, 1979, 240-243. 


\section{SU FUNCIONALIDAD JURÍDICA}

A la vista del reconocimiento constitucional de la posibilidad de Regiones uniprovinciales o de Provincias cuyas comunidades respectivas reúnan las condiciones necesarias para ser consideradas $\mathrm{Re}$ giones-esto es, Provincias-Regiones-, cabe desde luego preguntarse por el significado que en concreto para ellas-que ya disponen de unas Entidades autónomas cuales son las Provincias-puede tener el derecho a la autonomía reconocido en el artículo $2 .^{\circ}$ de la Constitución y la posibilidad de su constitución en Comunidades Autónomas conforme al Título VIII de la misma. Porque ciertamente la Provincia, como hemos tenido ocasión de indicar en páginas anteriores, "gozan de autonomia para la gestión de sus respectivos intereses" (artículo 137), que son lógicamente los intereses específicos de las comunidades respectivas, formadas, como sabemos, por agrupación legal de los Municipios correspondientes. La Diputación o el órgano que en su caso tenga encomendado el gobierno y administración de la Provincia es quien representa a la comunidad social provincial y quien, con los instrumentos y recursos proporcionados por la ley, trata de atender directamente o de procurar que se satisfagan las necesidades que dicha comunidad tenga como tal comunidad provincial. Y esa actividad política y administrativa le corresponde a la Entidad provincial-a sus órganos de gobierno y de dirección administrativa-en régimen de autonomía, conforme a la nueva Constitución.

Pues bien, la relevancia jurídica de que una Provincia sea por uno u otro camino reconocida como Región es múltiple y de considerable trascendencia.

\section{A) Superior rango constitucional del derecho regional a. la autonomía}

En primer lugar, sólo las Regiones gozan de un derecho a la autonomía que podríamos calificar como fundamental en el orden político establecido por la Constitución de 1978. Reconocido en el artículo 2. del Título Preliminar de la Constitución, su supresión como tal derecho genérico a la autonomía equivaldría a una revisión total de la Constitución, que tendría que producirse por el proce- 
dimiento cualificado que establece el artículo 168 del mismo texto constitucional. Y ello porque el constituyente ha querido establecer como esencial o fundamental a la estructura política de España la existencia de unas Regiones autónomas, que ostenten poderes públicos cuyo ejercicio puedan asumir en condiciones de libre autodeterminación, sin controles por parte del Estado que excedan de lo necesario para garantizar la legalidad-incluyendo naturalmente en este concepto la constitucionalidad-.

Frente a la naturaleza de las Administraciones locales-Municipios, Provincias, etc.-, e incluso de las mismas Comunidades Autónomas, que pueden ser suprimidas o reformadas-al menos desde una consideración estrictamente jurídico-formal-por el procedimiento de revisión simple de la Constitución que regula el artículo 167 de la misma, el reconocimiento de que la Nación española está integrada por Regiones autónomas y solidarias entre sí goza del más alto rango jurídico-formal de índole constitucional. Nótese bien que hemos dicho que ni siquiera la regulación actual de las Comunidades Autónomas en el Título VIII y otros preceptos dispersos del texto constitucional se beneficia del mismo rango constitucional que el derecho a la autonomía regional del artículo 2.․ Por ello, mediante el procedimiento de revisión constitucional simple se puede, desde luego, en cualquier momento, dar un nuevo contenido constitucional a dicha autonomía regional, uniformando posibilidades, reduciendo o aumentando poderes y competencias, etcétera. Llevando las cosas al límite, puede decirse que incluso cabría que, sin perjuicio de la integridad del artículo $2 .^{\circ}$, en una reforma parcial de la Constitución se desconstitucionalizara por entero la regulación del contenido del derecho a la autonomía regional y del reconocimiento mismo de las Regiones, con lo que todo quedaría a la potestad legislativa de las Cortes, las cuales, sin embargo, estarían obligadas a hacer esa regulación. Lo más razonable, con todo, es que sea la misma Constitución quien, como lo hace hoy o de otra forma, trace las normas básicas en esas materias definiendo o determinando el contenido del artículo $2 .^{\circ}$ de forma que no quede todo al criterio más fácilmente mudable del poder legislativo de las Cortes Generales.

En conclusión, mientras que la Constitución sitúa al máximo nivel de fundamentalidad la necesidad de alguna suerte de institucionalización autónoma de las Regiones, la existencia institucionalizada de Municipios y Provincias tiene un rango inferior en este 
sentido. Incluso las Comunidades Autónomas, como tales, en su actual configuración constitucional, tienen también un rango inferior, como hemos tratado de explicar, aunque esta forma concreta de institucionalizar las Regiones que son las Comunidades Autónomas no debe confundirse con aquella exigencia fundamental de que las Regiones se institucionalicen y con carácter autónomo de algún modo. Pero el establecimiento de una Comunidad Autónoma equivale a reconocer la existencia de una Región titular del derecho fundamental del artículo $2 .^{\circ}$ de la Constitución (55). A partir de este momento una reforma simple de la Constitución podrá modificar o incluso suprimir la Comunidad Autónoma, pero no el derecho a que se institucionalice una autonomía regional para la correspondiente colectividad territorial.

\section{B) Carácter paccionado del Estatuto de Autonomía}

El Estatuto jurídico de la Comunidad Autónoma que se constituya va a poder beneficiarse de un cierto carácter paccionado entre la Región y las Cortes, tanto en el proceso de su elaboración como, sobre todo, en cuanto a su ulterior modificación, reforma o supresión, ya que cuando menos es posible que se le dote de tal rigidez que las Cortes Generales del Estado pierdan su potestad de alterarle unilateralmente como no sea yendo a los procedimientos de revisión constitucional (56). Ello quiere decir que las competencias que

(55) Posiblemente habría que exceptuar de estas implicaciones los supuestos de imposición de Estatuto de Autonomía contemplados en el artículo 144, b) y c), micntras no conste suficientemente la existencia sociológica de una Región.

(56) Cfr. artículos 146, 147, 1 y 3: 151 y 152, 2, de la Constitución, artículos 46 y ss. del Estatuto Vasco y 56 y ss. del Estatuto de Cataluña, y artículo 52 del Proyecto de Estatuto de Asturias (que se tramita por la vía ordinaria del 143 y ss. de la Constitución). Vid. también García de Enterría. E., y Fernández, T. R.: Curso..., I, 3. ${ }^{2}$ ed., cit., 262-265, y EnTrena Cuesta, R.: Curso..., 1, 6. ${ }^{2}$ ed., cit., 107 y ss. Se ha cuestionado que fuera de la vía del artículo 151 sea constitucional la pérdida de poder legislativo que para las Cortes implica la necesidad de consentimiento regional en la reforma del Estatuto. Cfr. en tal sentido López Rodó, L.: Las autonomías, encrucijada de España, Aguilar, Madrid, 1980, 51-52, 60 y ss., y Piruela constitucional, diario $A B C, 29$ de noviembre de 1980, 9, y ToRnos MAS, J.: Los Estatutos de las Comuniclades Autónomas en el ordenamienio jurídico español, "RAP», núm. 91, enero-abril $1980,144-145,147-148$ y 151.

Sin embargo, la tesis de que la ley orgánica que ha de aprobar el Estatuto de Autonomía de las Comunidades que se establezcan por la vía del artículo 146 es una ley orgánica común y, por ende, exclusivamente sometida al régimen dispuesto en el artículo 81 de la Constitución. no me parece aceptable. Según la Constitución, a excepción del supuesto del artículo $144, b$ ), las Cortes Generales no pueden acordar 
se asignan por vía estatutaria a la Comunidad Autónoma (57) no podrán serle retiradas unilateralmente de forma ordinaria por el Estado, a diferencia, claro está, de lo que ocurre con las competencias de las Administraciones locales, que están siempre bajo la dis-

un Estatuto de Autonomía sin seguir al menos el procedimiento regulado en el artículo 146, y, por tanto, sin que se produzca la iniciativa y la propuesta de la comunidad territorial interesada. Las Cortes carecen, pues, de iniciativa ordinaria en esta materia, aun cuando, haciendo uso de las facultades extraordinarias del artículo 144, c), puedan suplir la primera iniciativa o iniciativa inicial del procedimiento, que no equivale a lo que en rigor se denomina iniciativa legislativa, la cual efectivamente corresponde en todo caso a la Asamblea estatuyente-proponente del artículo 146. La tramitación como ley del proyecto de Estatuto de Autonomía no eliminará la realidad de que la intervención de las Cortes Generales habrá de tener un sentido de acto aprobatorio, al menos materialmente y sin perjuicio de las modificaciones que puedan introducirse en el proyecto. Y políticamente es indudable que todo ello va a estar presidido por un ineludible tono paccionado, si no se quiere convertir en irrelevante la propuesta que elabore la Asamblea regional del artículo 146. Y si éste va a ser de hecho-con fundamento evidente en las normas constitucionales-el procedimiento de aprobación del Estatuto de Autonomía, es razonable que para su modificación se formalicen exigencias similares, de manera que solas las Cortes no ostenten la potestad de modificar una ley orgánica-la del Estatuto-que tampoco por sí mismas tienen la potestad de establecer. Si la Constitución ha condicionado en este punto la potestad legislativa de las Cortes Generales, exigiendo la iniciativa legislativa regional para crear una Comunidad Autónoma, cabe igualmente entender de modo coherente que ese mismo condicionamiento pueda disponerse para modificarla. Sólo que, al mismo tiempo, para mantener también la coherencia con la naturaleza aprobatoria de la iqutervención de las Cortes en el procedimiento de creación de la Comunidad, convendrá prever asimismo la iniciativa de la reforma o modificación a las Cortes, sin per. juicio de que en dicho procedimiento deba contarse con la voluntad de la Comunidad interesada.

En cuanto a la supresión de la Comunidad, como, una vez que se reconoce como tal, ello implica reconocer una Región con el derecho fundamental a su autonomía, declarado en el artículo $2 .^{\circ}$, no parece que las Cortes Generales puedan suprimirla sin más, como no sea acudiendo a los procediminetos de revisión constitucional. No será, pues, suficiente con una ley orgánica común. Habrá que ir a la revisión constitucional o atenerse a los procedimientos que se fijen en el Estatuto, que lógicamente serán de la misma naturaleza paccionada que para su reforma o modificación.

Anotemos finalmente que-contra lo que afirma el Profesor LÓPEz Rodó (Las autonomías..., loc. cil. supra)-no me parece que en los Estatutos de Autonomía y por causa de su naturaleza paccionada se produzca una cesión de soberania. En efecto, ésta reside en el pueblo español y en nadie más, y se manifiesta como poder constituyente que delimita los perfiles institucionales y las competencias de los órganos del Estado y reserva al pueblo mismo algunas decisiones o funciones de especial trascendencia. Las Cortes Generales no tienen sino las competencias que dentro de ciertos límites les otorga la Constitución, y si representan al pueblo español (art. 66) es solamente a esos efectos, sin asumir por ello la plenitud soberana que sólo en el pueblo permanece.

(57) Las competencias de las Comunidades Autónomas, por razón del título de atribución, podrán ser estatutarias y extraestatutarias. El artículo 150,1 y 2 , contempla los supuestos de delegación legislativa y de descentralización y delegación administrativa del Estado en las Comunidades Autónomas, que son vías extraestatutarias de atribución de competencias a estas Entidades. Vid. un comentario en MuÑoz Machado, S.: Las potestades legislativas de las Comunidades Autonomas, Cuadernos Civitas, Madrid, 1979, especialmente en págs. 40 y s. Cfr. también Tornos Mas, J.: Los Estatutos..., cit., 156. 
ponibilidad del Poder legislativo que se las asigne, sea el del Estado, sea eventualmente el de una Comunidad Autónoma-sin perjuicio del control de constitucionalidad del Tribunal Constitucional acerca de las exigencias mínimas que puedan derivarse de la configuración que la Constitución hace de la Administración local-.

\section{C) La potestad legislativa}

Dentro de lo que supone la actual regulación constitucional de las Comunidades Autónomas, el que una Provincia se constituya en este tipo de Entidad pública representa, según general interpretación doctrinal (58), que la autonomía va a incluir no solamente potestades administrativas, sino también potestad legislativa, con lo que ello implica, al menos en principio, de mayor capacidad de incidencia en la realidad social y en la ordenación de la colaboración social necesaria para lograr satisfacer del mejor modo las necesidades e intereses de la comunidad regional (59).

\section{D) La ampliación de competencias administrativas $y$ de recursos económicos}

Suele entenderse que es éste otro de los beneficios que la institucionalización de una Comunidad Autónoma puede traer consigo por comparación o contraste con la mera Provincia-Entidad local.

La cuestión, sin embargo, puede y debe ser relativizada. La naturaleza propia de la Provincia-Entidad local admite sin problemas

(58) Cfr. García de Enterría, E., y Fernández, T. R.: Curso..., I, 3. ${ }^{a}$ ed., cit., 265. 267; Muñoz Machado, S.: Op. cit., supra: Entrena Cuesta, R.: Curso..., I-1, 6. ${ }^{2}$ edición, 98 y ss.; Boquera Oliver, J. M..: Derecho Administrativo. I, 3." ed.. cit.. 131; GArrido Falla, F.: Tratado..., I, reimpr. 7." ed., CEC, Madrid, 1980, 646-647, y López RoD6, L.: Las autonomias..., cit., 89.

Un enfoque del tema particularmente crítico y agudo en González Navarro, F.: Potestad legislativa del Estado y potestad reglamentaria autónoma de las Nacionalidades y Regiones, en "La Constitución española y las fuentes del Derecho", vol. II, IEF, Madrid, 1979, $1021-1157$.

(59) Se trata, sin embargo, de una potestad legislativa que, salvo algún supuesto, estará subordinada a leyes orgánicas, leyes básicas y leyes armonizadoras del Estado. Rara será la materia confiada a la regulación normativa exclusiva de una Comunidad Autónoma, al menos en la práctica. De ahí el acierto de la dirección interpretativa adoptada por GoNZÁlez NAVARRo en el trabajo citado en nota anterior. Inciden en el tema Muñoz Machado, S.: Las competencias en materia econónica del Estado y de las Comunidades Autónomas, y García de EnTERría, E.: Estudio preliminar, ambos en «La distribución de las competencias económicas entre el poder central y las autonomías territoriales en el Derecho Comparado y en la Constitución española», IEE, Madrid, 1980, págs. 309 y ss. y 11 y ss., respectivamente. 
que sea recipiendaria o destinataria de tanta descentralización y autonomía administrativas-con la consiguiente dotación de medios económicos-como una Comunidad Autónoma (60). El que pudiera facilitarse esa ampliación en competencias, medios y autonomía por medio de un régimen jurídico especial o una Carta específica, o, simplemente, mejorando los dispositivos orgánicos ejecutivos de la organización actual de las Provincias de régimen común, es, a la postre, algo indiferente a la afirmación que acabamos de establecer, ya que nada de ello afecta a lo que es esencial a la Provincia como Entidad local. Por lo demás, ahí está el caso de Navarra, que, sin dejar de seguir siendo una Provincia, es una Región que ha dispuesto, dispone y puede llegar a disponer de tanta autonomía administrativa como cualquier Comunidad Autónoma, llegando a contar incluso con un régimen económico de concierto, cuya aceptabilidad respecto a las Comunidades Autónomas ha suscitado vivas polémicas.

\section{E) Especiales derechos constitucionales de participación cooperativa en el Estado}

La Constitución, en diversos preceptos, otorga a las Comunidades Autónomas potestades de participación en órganos o en funciones del Estado que no reconoce a las Administraciones locales.

En primer término, cada Comunidad Autónoma designará un Senador y otro más por cada millón de habitantes de su respectivo territorio, correspondiendo dicha designación al órgano colegiado superior de la Comunidad (artículo 69, 5). Cierto que hay también cuatro Senadores por cada Provincia, como ya hemos recordado en este mismo trabajo (artículo 69, 2), pero, aparte de que estos Senadores provinciales son elegidos por sufragio directo de la pobla-

(60) Sobre la distinción entre autonomía y descentralización con carácter general y más específicamente con aplicación a la Administración territorial. vid. Ś́NCHEZ. Díaz, I. L.: Competencia y autonomía municipal, en esta RevistA, núm. 205, eneromarzo 1980,99 y ss.

En cuanto a la aptitud de la Provincia para ser titular de tan amplias competen. cias administrativas como pueda serlo una Comunidad Autónoma da una idea la simple lectura de los artículos 242 y 243 de la Ley de Régimen local de 1955. Al tema me referí hace unos años en una comunicación a la III Reunión de Estudios Regionales que tuvo lugar en Oviedo en octubre de 1976. Cfr. MARTínez LÓPEZ-MUÑ IZ, J. L.: La Provincia como escalón regional de la Administración Pública, difundido a ciclos. tilo entre los participantes en la citada Reunión. Cfr. también Vallina Velarde, I. L. DE LA: Discurso, 8 de febrero de 1976, Imp. "Boletín Oficial» de la Provincia, Oviedo, 1976, 15. 
ción provincial-lo que supone una marginación de la Entidad local provincial en esta elección-, es evidente que en cualquier caso la constitución de una Comunidad Autónoma supondrá un plus de presencia, de participación de la Región correspondiente en el Senado y por tanto en el Legislativo del Estado (61).

Además, el artículo 87 reconoce a las Comunidades Autónomas potestad de iniciativa legislativa respecto a la legislación estatal:

"2. Las Asambleas de las Comunidades Autónomas podrán solicitar del Gobierno la adopción de un proyecto de ley o remitir a la Mesa del Congreso una proposición de ley, delegando ante dicha Cámara un máximo de tres miembros de la Asamblea encargados de su defensa."

Por otra parte, el artículo 131, 2, establece que los proyectos de planificación del Gobierno habrán de elaborarse de acuerdo con las previsiones suministradas por las Comunidades Autónomas.

Finalmente, el artículo 152, 1, admite la participación de las Comunidades Autónomas en «la organización de las demarcaciones judiciales del territorio", de acuerdo con lo que al efecto dispongan los Estatutos, de conformidad con lo previsto en la Ley Orgánica del Poder judicial y dentro de la unidad e independencia de éste.

\section{F) Tribunal Superior de Justicia para el territorio regional}

Podría parecer que nos encontramos ante otra de las diferencias que median entre la situación de una comunidad o de un territorio en el que solamente está institucionalizada la Provincia y la de aquellos en que se constituye una Comunidad Autónoma. Hay que advertir, sin embargo, que la existencia de tal Tribunal Superior de Justicia solamente la prevé expresamente-imponiéndola-el artículo 152, 1, de la Constitución para las Comunidades Autónomas establecidas por el procedimiento especial del artículo 151. Se entiende, con todo, que la Ley Orgánica del Poder judicial o los Estatutos de Autonomía pueden crear ese tipo de Tribunal en cualquier territorio con Comunidad Autónoma. Por las mismas razones-pienso-cabría establecer un Tribunal Superior en una circunscripción provincial sin Comunidad Autónoma: es algo que no afecta en rea-

(61) Vid. sobre la distinta naturaleza de la representación y del carácter de los Senadores provinciales y regionales o comunitarios el excelente trabajo de Ramón PUNSET: El concepto de representación territorial en la Consitución española de 1978. en "Revista del Departamento de Derecho Político» (UNED), núm. 7, otoño 1980, 105-118. 
lidad directamente ni a la naturaleza de las Comunidades Autónomas ni a la de la Provincia-Entidad local, sino a la estructura del Poder judicial, que es único para toda la Nación y radicado en el Estado, según nuestra actual Constitución. Cierto es, sin embargo, que buena parte de la justificación del Tribunal Superior-complemento en realidad de las tradicionales Audiencias Territoriales; que tenían ya una dimensión supraprovincial-radica en la existencia de leyes de las Comunidades Autónomas respectivas, tanto en el ámbito civil como en el administrativo, pero ni siquiera esto es un elemento de radical separación con lo que pudiera ocurrir con respecto a las Provincias, ya que éstas pueden estar dotadas de una amplia potestad reglamentaria que, al menos en cuanto a lo administrativo, podría justificar de semejante forma una instancia judicial ante la que se agoten las apelaciones correspondientes, sin perjuicio de la casación o de los posibles recursos extraordinarios ante el Tribunal Supremo.

En este punto, por tanto, la constitución de la Comunidad Autónoma en una Región uniprovincial no tiene por qué considerarse necesaria para disponer en ella de un Tribunal Superior de Justicia, que bien podría llegar también a implantarse en tal territorio aun sin Comunidad Autónoma (62).

\section{G) Control y garantía de su autonomía por el Tribunal Constitucional}

Es una de las grandes peculiaridades de las Comunidades Autónomas, frente a lo que es propio del régimen jurídico aplicable a

(62) No me parece correcto afirmar que el Tribunal Superior de Justicia sea una institución de la Generalitat impuesta por la propia Constitución, o que venga a completar el carácter de ente político de ésta, al poseer Parlamento, Ejecutivo y un Tribunal Superior, como llega a decir ToRnos MAS, I., en Las competencias de la Generalitat en el Estatuto de Cataluña, en esta RevisTa, núm. 205, enero-marzo 1980, 82. La Generalitat no goza de un Tribunal Superior de Justicia precisamente porque, como el mismo Tornos Mas reconoce, el Poder judicial es único según la Constitución y, "por tanto, la función y el órgano son de titularidad estatal» (ibídem). El Tribunal Superior de Justicia es un órgano del Poder judicial del Estado para la Región correspondiente, pero en modo alguno pertenece a la Comunidad Autónoma, a su organización propia. Y desde luego los Estatutos de Autonomía no son. la norma apropiada para regular ese órgano judicial que, como los demás del Poder judicial, deben regularse por su correspondiente ley orgánica. Los Estatutos son leyes orgánicas, pero de naturaleza especial, como es sabido; no deben regular por ello lo que según la Constitución es materia de ley orgánica ad hoc; y si lo regulan, habrá que considerar que en esa materia el Estatuto no se beneficiará de su naturaleza paccionada, pudiendo ser modificado por leyes orgánicas comunes (unilaterales) de las Cortes Generales. 
las Administraciones locales. En primer término porque el control de la autonomía de éstas está encomendado a los Tribunales ordinarios, señaladamente a los de la Jurisdicción contencioso-administrativa-sin perjuicio, claro está, en último extremo de la posibilidad de intervención del Tribunal Constitucional por la vía del recurso de amparo-, mientras que respecto a la autonomía de las Comunidades Autónomas el Tribunal Constitucional se erige en el principal organismo de control, aunque también coexista con él en dicha función la Jurisdicción contencioso-administrativa, como la Constitución, en el artículo 153, c), ha dejado establecido (63).

(63) La Constitución ha entregado al Tribunal Constitucional el control de la constitucionalidad de sus disposiciones normativas con fuerza de ley [art. 153,a)], pero no el control "de la administración autónoma y sus normas reglamentarias», que el artículo $153, c)$, confía expresamente a la Jurisdicción contencioso-administrativa. Sin embargo, las Cortes Generales vieron en el artículo $161,1, c)$-conflictos de competencia entre el Estado y las Comunidades Autónomas-, y 2-legitimación del Go. bierno para impugnar ante el Tribunal Constitucional con efectos suspensivos «las dis. posiciones y resoluciones adoptadas por los órganos de las Comunidades Autónomas»-, un portillo para ensanchar la competencia del Tribunal Constitucional a costa de la Jurisdicción contencioso-administrativa. $\mathrm{Y}$ así, con discutible constitucionalidad, puesto que debería haberse puesto en relación el artículo 161,2, con el artículo 153, la Ley Orgánica del Tribunal Constitucional, en su artículo 76 , ha interpretado que la potestad del Gobierno para impugnar ante el Tribunal Constitucional con efectos suspensivos disposiciones y resoluciones de las Comunidades Autónomas se refiere no solamente a las que tengan fuerza de ley-a las que menciona expresamente el ar. tículo 30 de la Ley Orgánica, correctamente-, sino también a las sin fuerza de ley emanadas de cualquier órgano de dichas Comunidades. $Y$ ahí tenemos al Tribunal Constitucional convertido en juez no solamente de los Poderes legislativos. como es su función principal, sino también de la Administración y al margen de las posibilidades del recurso de amparo. Por otra parte, además, la Ley Orgánica ha hecho una curiosa regulación de los llamados conflictos constitucionales. Entiende por tales los que «se susciten sobre las competencias o atribuciones asignadas directamente por la Constitución, los Estatutos de Autonomía o las Leyes orgánicas u ordinarias dictadas para delinitar los ámbitos propios del Estado v las Comunidades Autónomas" (artículo 59). con lo que sitúa ya de entrada al Tribunal Constitucional en un terreno que excede en rigor de su función de intérprete supremo de la Constitución, haciéndole intervenir en problemas de interpretación de leyes incluso ordinarias con vistas a la declaración de conformidad o disconformidad de actuaciones administrativas-aunque sólo en cuanto a la competencia o incompetencia del órgano correspondiente-al Ordenamiento jurídico. Y no contenta con eso la Ley Orgánica desnaturaliza la figura de los conflictos positivos de competencia que siempre se habian referido entre nosotros a litigios planteables antes del ejercicio efectivo de una competencia, convirtiendo este cauce de los conflictos constitucionales positivos en una vía pura y simple de impugnación de disposiciones o resoluciones de las Comunidades Autónomas por parte del Gobierno o de otras Comunidades Autónomas, y de disposiciones o actos del Estado, por parte de una o varias Comunidades Autónomas (arts. 62 y ss. de la Ley Orgánica). Tampoco aquí tuvieron en cuenta al hacer la Ley Orgánica que el artículo $161,1, c)$, tenía que interpretarse en combinación con el artículo 153 del mismo texto constitucional. La impugnación de disposiciones y actos debió limitarse a aquellos que tuvieran fuerza de ley, encauzándose por la vía del recurso de inconstitucionalidad o de la cuestión de inconstitucionalidad. Y los conflictos de competencias debieron regularse precisamente en cuanto a las competencias legislativas $y$ para antes de la definitiva perfección de las correspondientes leyes, o disposiciones y 
En segundo término, en cuanto a la garantía y defensa de la autonomía, es cierto que el Tribunal Constitucional deberá custodiar también la autonomía local-de la Administración local-, ya que es un principio constitucional que deberá ser respetado y hecho efectivo por las leyes y normas con fuerza de ley sometidas a la jurisdicción de dicho Alto Tribunal, pero las invasiones de esa autonomía procedentes de la acción reglamentaria y administrativa de la Administración del Estado o de una Comunidad Autónoma o, en fin, de otra Administración cualquiera, tendrán que ser rechazadas acudiendo a los Tribunales contencioso-administrativos de la Jurisdicción ordinaria. Y además resulta que ni la Constitución ni la Ley Orgánica del Tribunal Constitucional han legitimado a las Administraciones locales para interponer el recurso directo de inconstitucionalidad contra leyes y disposiciones normativas con fuerza de ley, con lo que su iniciativa defensiva solamente podrá operar ante asuntos concretos o ante reglamentos, por la vía de la cuestión de inconstitucionalidad que pueden y deben promover los Tribunales, a tenor del artículo 163 de la Constitución y 35 y siguientes de la Ley Orgánica del Tribunal.

En cambio, con respecto a las Comunidades Autónomas, la Constitución legitima expresamente a sus órganos colegiados ejecutivos superiores y, en su caso, a sus Asambleas, para interponer el recurso directo de inconstitucionalidad contra leyes y disposiciones norma-

actos con fuerza de ley. La Jurisdicción contencioso-administrativa habría seguido siendo así la única competencia en el enjuiciamiento de la Administración. sin perjuicio del juego eventual de la cuestión judicial de inconstitucionalidad y del recurso de amparo.

En la redacción de la LOTC ha pesado quizá en exceso el modelo del Tribunal de Karlsruhe, olvidando que la Constitución española no ha federalizado el Poder judicial. Se ha perdido, en cambio, la oportunidad de atribuir al Tribunal Constitucional los conflictos jurisdiccionales entre el Poder judicial y las Administraciones públicas, lo que va a tratar de ser subsanado por la Ley Orgánica del Poder Judicial mediante la creación de un Tribunal de Conflictos de inspiración francesa (art. $35 \mathrm{dcl}$ Proyecto de Ley Orgánica de 2 de noviembre de 1979): ambas alternativas al sistema tradicional de nuestro Derecho positivo fueron propuestas por PARADA VázouEz. J. R., en Los conflictos entre la Administración y los Tribunales ante la nueva Constitución, «RAP», 84, septiembre-diciembre 1977, 567. El que el Tribunal Constitucional hubiera de entrar en estos casos en la interpretación de normas del Ordenamiento muy alejadas del nivel constitucional, estaría sobradamente justificado por la índole del con. flicto a resolver, que requiere en buenos principios un Juez independiente e imparcial respecto de las partes en litigio. La solución del Tribunal de Conflictos no parece contemplar la importante realidad de nuestro nuevo sistema administrativo autonómico. 
tivas con fuerza de ley [artículo 162, 1, a)] (64) y constituye al Tribunal Constitucional en juez de los conflictos de competencia entre el Estado y las Comunidades Autónomas o de los de éstas entre sí [artículo $161,1, c)$ ], lo que, por cierto, ha sido desarrollado por la Ley Orgánica del Tribunal de modo un tanto discutible y que roza incluso la inconstitucionalidad (65). Es decir, la Constitución ha querido avalorar el significado y solidez de la autonomía de las Comunidades Autónomas encomendando de modo especial su custodia al Tribunal Constitucional y facilitando para ello el acceso al mismo a las correspondientes Comunidades. Ello es además básicamente una consecuencia de la posibilidad de que las Comunidades Autónomas sean titulares o ejerzan potestades legislativas, ya que es cabalmente el Tribunal Constitucional el único juez de los legisladores, en nuestro sistema constitucional.

\section{H) Diferencias en los controles de la Administración estatal sobre Administraciones locales y Comunidades Autónomas}

Aunque los controles propiamente de tutela habrán de desaparecer, incluso con respecto a la Administración local, en razón de la autonomía que en su favor declara la Constitución (66), parece lógico que subsistan en manos de la Administración estatal o de las Comunidades Autónomas (67) algunas técnicas imprescindibles

(64) Cfr. también el artículo 32, 2, de la LOTC, que determina que dicha legitimación se refiere únicamente a los recursos contra leyes, disposiciones o actos con fuerza de ley del Estado que puedan afectar al propio ámbito de autonomía de cada Comunidad Autónoma.

Sobre la falta de legitimación de las Administraciones locales, cfi: BOCANEGRA SIERRA, R.: Nueva configuración..., cit., 374-375.

(65) Cfr. lo que decimos supra en nota 63.

(66) Cfr. Bocınegra Sierra, R.: Nueva configuración..., cit., 369 y ss.; Sánchez DíAz, J. L.: Competencia y autonomía municipal, cit., 99 y ss.; BoQuera Oliver, J. M.": Derecho Administrativo, I, 3." ed., cit., 308-309; ARCE MONZ6́N, L.: La autonomía municipal en el Derecho español, «Revista Jurídica de Asturias», núm. 2, julio-diciembre, 1979, 136. Cfr. también al respecto el Real Decreto 1710 , de 16 de junio de 1979 , clictado en uso de la autorización dada al Gobierno por el artículo 2..$^{\circ}$ de la Ley 47, de 7 de octubre de 1978.

(67) El artículo 148 de la Constitución contempla expresamente en el apartado 1 como competencias asumibles por las Comunidades Autónomas «las funciones que correspondan a la Administración del Estado sobre las Corporaciones locales y cuya transferencia autorice la legislación sobre Régimen local». Por su parte, el artículo 149 sólo reserva al Estado «las bases del régimen juridico de las Administraciones públicas", lo que permite transferir a las Comunidades amplias competencias en cuanto a la legislación y control sobre las Corporaciones locales-de ordinario solamente de legalidad y conforme a los criterios que se apuntan por la doctrina señalada en la nota anterior (66) - Sobre el tema, cfr. Bocanegra SiERRA, R.: Op. cit., supra, 388 y ss. Cfr. también Estatuto Vasco, artículo 10, 3 y 4, y artículo 37; Estatuto de Cataluña, artículo 9., 8, y artículo 5.\%; Proyecto de Estatuto de Autonomía para Asturias, artículo 11, 1,a), y Estatuto de Galicia (BOE, 8-XI-80), artículo 27, 2. 
para garantizar la salvaguarda del interés general en supuestos de grave infracción de la legalidad o de la constitucionalidad, impidiendo la actuación de los efectos propios de la ejecutividad de los actos públicos, por una parte, y abriendo el paso con las garantías necesarias a la adopción de medidas excepcionales o extraordinarias que en determinadas circunstancias puedan resultar imprescindibles, por otra. En este sentido es probable que se mantengan los poderes de suspensión por razones de legalidad con inmediato control ulterior de los Tribunales contencioso-administrativos, así como las potestades de intervención y tutela actualmente reguladas en el capítulo IV del Título V del Libro III de la Ley de Régimen local, aunque se revise la actual regulación concreta de aquéllos y éstas.

Pues bien, paralelamente la Constitución prevé el juego de técnicas similares de control por parte del Gobierno estatal sobre las Comunidades Autónomas, pero con diferencias derivadas del distinto rango constitucional que, como estamos viendo, tienen las Comunidades Autónomas en comparación con las Administraciones locales.

En efecto, como ya hemos citado, el artículo 161, 2, prevé la impugnación por el Gobierno ante el Tribunal Constitucional de disposiciones y resoluciones de las Comunidades Autónomas, la cual producirá el efecto de la inmediata suspensión de la disposición o resolución recurrida, teniendo el Tribunal la facultad de ratificar o levantar tal suspensión en plazo no superior a cinco meses. Con variaciones en la articulación técnica de la suspensión, la similitud con la suspensión de acuerdos de las Corporaciones locales por causa de infracción manifiesta de las leyes (68) es patente. Destaca,

(68) Cfr. LJ, artículo 118. Además, cabe la suspensión administrativa, sometida a ulterior impugnabilidad mediante recursos administrativos y contencioso-administrativos, por razón de incompetencia según las leyes o por razón de contenido constitutivo de delito (art. $362,1,1^{\circ}$ y $22^{\circ}$, de la LRL) y por razón de ser los actos contrarios al orden público (art. $362,1,3 .^{a}$, de la misma LRL), causa esta última que probablemente sea revisada en la futura legislación del Régimen local. En realidad, no parece lógica la diferencia de trato que muestra la actual legislación entre la falta de competencia-cualquier falta de competencia-y la infracción manifiesta "de las leyes. $\mathrm{Y}$ en cuanto a los supuestos en que el acto de la Corporación constituya delito se trata también de una causa de suspensión de dudosa admisibilidad como algo distinto de la infracción manifiesta de las leyes, ya que, en rigor, sólo los Tribunales penales pueden determinar la existencia de un delito, y si el carácter delictivo es de indudable importancia en cuanto a la validez o nulidad radical del acto-LPA, artículo $47,1, b)-$, la suspensión solamente podrá recaer en base a indicios de la existencia de un delito, pero no porque constituya tal acto un delito. En este sentido es más adecuada la fórmula empleada por el artículo 116 de la LPA, aplicable supletoriamentc a la Administración local (LPA, art. 1., 4). Por lo demás, llama la atención y es significativo que la LRL solamente prevea la suspensión de acuerdos de los órganos 
sin embargo, esta doble diferencia: es el Gobierno y no su Delegado ante la Comunidad Autónoma (69) quien tiene la correspondiente competencia; y es el Tribunal Constitucional y no la Jurisdicción contencioso-administrativa quien en estos supuestos juzgará definitivamente sobre la validez de la suspensión. Es además, en definitiva, la Administración del Estado quien en este sentido controla a las Comunidades Autónomas, mientras que lo más probable sea que en el futuro quienes controlen a las Administraciones locales sean las Administraciones de las Comunidades Autónomas.

Por otra parte, en segundo lugar, el artículo 155 de la Constitución establece, como es sabido, que:

"1. Si una Comunidad Autónoma no cumpliere las obligaciones que la Constitución $u$ otras leyes le impongan, o actuare de forma que atente gravemente al interés general de España, el Gobierno, previo requerimiento al Presidente de ia Comunidad Autónoma y, en el caso de no ser atendido, con la aprobación por mayoría absoluta del Senado. podrá adoptar las medidas necesarias para obligar a aquélla al cumplimiento forzoso de dichas obligaciones o para la protección del mencionado interés general.»

Es decir, nada menos que la autorización del Senado, por mayoría absoluta de éste, es paso imprescindible al Gobierno para poder adoptar medidas especiales-extraordinarias y excepcionales- de intervención y tutela- "podrá dar instrucciones", concreta el número 2 del mismo artículo constitucional-sobre las Comunidades Autónomas, mientras que la Ley de Régimen local en los artículos 422 y siguientes no pasa de exigir, como garantía máxima, en cuanto a dichas medidas sobre las Corporaciones locales, el acuerdo del Consejo de Ministros, exigencia ésta que probablemente desaparezca si se transfieren estas competencias actuales del Estado a las Comunidades Autónomas (70) (71).

colegiados de las Entidades locales y no la de los actos de Alcaldes y Presidentes de las correspondientes Corporaciones, en cuanto titulares que son de competencias propias. Parece lógico corregir en el futuro esta omisión.

(69) Cfr. Constitución, artículos 154 y 161, 2. Sobre los Delegados del Gobierno en las Comunidades Autónomas, Real Decreto 2238, de 10 de octubre de 1980 (BOE del 22).

(70) Podría establecerse entonces la exigencia de que la Asamblea Legislativa o máximo órgano de la Comunidad Autónoma tenga que aprobar esas medidas excepcionales.

(71) No hemos hecho referencia aquí más que a un análisis comparativo entre lo que es propio de la autonomía de las Comunidades regionales y de las Corporaciones locales, por razón cabalmente del distinto régimen jurídico de ambas autono- 
IV. NATURALEZA MIXTA PROVINCIAL-REGIONAL DE LAS COMUNIDADES AUTONOMAS UNIPROVINCIALES

\section{Provincias y Comunidades Autónomas pluriprovinciales}

El artículo 143, 1, de la Constitución permite distinguir, como ya hemos señalado, unas Comunidades Autónomas pluriprovinciales y unas Comunidades Autónomas uniprovinciales (72). Pero tanto en un caso como en otro, dicho precepto otorga el protagonismo constituyente de cada Comunidad Autónoma a las Provincias, las cuales son-según se dice literalmente-quienes podrán así acceder a su autogobierno, precisamente al constituirse en Comunidades Autónomas.

Los efectos que, sin embargo, haya de tener en las correspondientes Provincias su constitución en Comunidades Autónomas no pueden ser los mismos, teniendo en cuenta el conjunto del ordenamiento constitucional establecido en 1978.

En cuanto a las Comunidades pluriprovinciales parece bastante claro que el artículo 143, 1, está remitiendo a la idea de un proceso asociativo o federativo interprovincial en la creación de cada Comunidad Autónoma. El texto del artículo 130 del anteproyecto de Constitución reelaborado por la Ponencia de la Comisión de Asuntos Constitucionales del Congreso de los Diputados (Boletin Oficial de las Cortes de 17 de abril de 1978, pág. 1596) era todavía mucho más explícito al decir que "las Comunidades Autónomas se basan en la libre asociación de las Provincias", sin que, por cierto, al sustituirse en el dictamen de la Comisión este texto por el que sería el actual artículo 137, se arguyera nada en contra del carácter asociativo interprovincial del proceso de constitución de dichas Comunidades Autónomas (73). En el artículo 136 del texto de la citada Ponencia-antecedente directo del actual 143-se decía también

mías. Aparte de ello es cierto que pueden establecerse controles de las Cortes o de la misma Administración del Estado en supuestos de delegación legislativa o administrativa y de descentralización administrativa complementaria, previstas en el artículo 150,1 y 2 , de la Constitución en beneficio de las Comunidades Autónomas, y-en el ámbito, claro está, puramente administrativo-en el Real Decreto 3046, de 6 de octubre de 1977, artículos 131 y ss., en favor de las Entidades locales. Vid. también en cuanto a la delegación en favor de Comunidades Autónomas el artículo 153, b), de la Constitución.

(72) Esta distinción terminológica la establece ya Guaita, A.: Las Regiones en la Constitución española de 1978, "RICA», 1979, 149.

(73) Cfr. DS, núm. 87,13 de junio de 1978,3224 y ss. 
explícitamente que "las Provincias (...) podrán asociarse enire sí en Comunidades Autónomas". Este texto fue asimismo sustituido en la Comisión por el que sería definitivamente al actual artículo 143, 1, acogiéndose sin discusión pública, también en este caso, una enmienda del Partido Socialista Obrero Español. Y hay que destacar que en la argumentación del Diputado socialista señor Sotillo MaRTí, que defendió esa enmienda in voce, no se hace referencia alguna que pudiera dar pie a entender que se rechazaba la idea asociativa interprovincial. Es más, esta idea está como aceptada en el ambiente general del debate sobre este precepto en el seno de la Comisión de Asuntos Constitucionales el día 14 de junio de 1978, donde intervino en concreto el señor LETAMENDía hablando incidentalmente, pero con reiteración, de ese proceso asociativo, sin que nadie opusiera razón alguna al respecto (74). Hay que entender, en consecuencia, que el cambio de fórmula de redacción se debió a otros motivos y no se quiso rechazar la idea de que las Comunidades Autónomas habrían de surgir por asociación de Provincias, idea que por lo demás tenía ya su antecedente en la Constitución de la II República, cuyo artículo 11 hablaba concretamente de la posibilidad de que "una o varias Provincias limitrofes (...) acordaran organizarse en Región autónoma para formar un núcleo políticoadministrativo, dentro del Estado español».

Pienso que puede decirse, en suma, que la Constitución contempla a las Comunidades Autónomas pluriprovinciales y, en consecuencia, a las correspondientes Regiones mismas, como agrupaciones inicialmente voluntarias de Provincias. Su naturaleza interprovincial se asemeja notablemente a la naturaleza intermunicipal de las Provincias, aunque en éstas la agrupación intermunicipal no tenga un carácter inicialmente voluntario (75). Es cierto, no obstante, que en el desarrollo de esta idea básica no siempre es clara y plenamente coherente la Constitución. En la iniciativa del proceso autonómico por el procedimiento ordinario se exige ciertamente el acuerdo de todas las Diputaciones provinciales interesadas, reforzado con el de las dos terceras partes de los Municipios cuya población represente,

(74) Cfr. DS, núm. 88, 14 de junio de 1978, 3253.

(75) Cfr. supra, apartado 11,2 y 3. Caben, sin embargo, los cambios de uno o varios Municipios de una a otra Provincia, y cabe incluso que varios Municipios intenten configurar una nueva Provincia. En todo caso será necesaria, como dijimos, una ley orgánica (art. 141, 1, in fine). En cuanto al carácter irreversible del régimen autonómico, vid. LÓPEZ RoDo, L.: Las autonomías..., cit., 75 y ss. 
al menos, la mayoría del censo electoral de cada Provincia. Pero el acuerdo de las Diputaciones puede sustituirse en prácticamente todos los casos por la iniciativa del Ente preautonómico correspondiente, en virtud de la Disposición Transitoria Primera de la misma Constitución, aunque no debe olvidarse la importante presencia de los representantes de las Diputaciones en los Organismos preautonómicos, especialmente una vez producidas las elecciones locales de 1979 (76). Por otra parte son las Diputaciones, junto con los parlamentarios de las Provincias afectadas, quienes forman las Asam-

(76) Salvo en la Generalidad provisional de Cataluña, donde eran mayoría, junto a los representantes de las Diputaciones, los Consejeros designados por el Presidentc (a su vez nombrado por Real Decreto a propuesta del Presidente del Gobierno del Estado) (Real Decreto-ley 41, de 29 de septiembre de 1977, arts. $4 .^{\circ}$ y $5 .^{\circ}$ ), en los demás Entes preautonómicos, junto a los representantes de las Diputaciones se encuentran los parlamentarios de las Provincias respectivas o sus representantes. La proporción de representantes de las Entidades provinciales y de parlamentarios elegidos en las correspondientes Provincias era o es paritaria en el Consejo General Vasco (Real Decreto-ley 1, de 4 de enero de 1978, art. 5.'), en el Consejo del País Valenciano (Real Decreto-ley 10, de 17 de marzo de 1978, art. 5. ${ }^{\circ}$ 2), Diputación General de Aragón (Real Decreto-ley 8, de 17 de marzo de 1978, art. 5., cuya letra c) emplea incluso la significativa expresión de: «un representante de los Municipios de cada una de las tres Provincias aragonesas elegidos por los representantes de los mismos en cada una de las Diputaciones Provinciales»), Consejo General de Castilla y León (Real Decreto-ley 20, de 13 de junio de 1978, art. 3., B) y Junta de Comunidades de la Región Castellano-Manchega (Real Decreto-ley 32, de 31 de octubre de 1978, artículo $4 .^{\circ}, 2$, y art. $\left.5 .^{\circ}, 1-b\right)$. Es superior en uno la representación de las Diputaciones en el Pleno de la Iunta de Andalucia, aunque inferior en uno en el Consejo Permanente de la misma Junta (Real Decreto-ley 11, de 27 de abril de 1978, art. 5. ${ }^{\circ}$ 2); es inferior-ocho representantes de las Diputaciones y once de los parlamentarios-en la Iunta de Galicia (Real Decreto-ley 7, de 16 de marzo de 1978, art. 4. ${ }^{\circ}$ ). En la Junta Regional de Extremadura, junto a cinco parlamentarios de cada una de las dos Provincias, hay un representante solamente de cada Diputación y seis representantes de los Municipios de cada Provincia, designados cada uno de ellos por seis distintos grupos de Municipios, debiendo designarse por compromisarios de los Ayuntamientos (Real Decreto-ley 19, de 13 de junio de 1978, art. 3.') En la Junta de Canarias los representantes de las Diputaciones son sustituidos por representantes de los Cabildos insulares, que son 21, junto a 15 parlamentarios (Real Decreto-ley 9, de 17 de marzo de 1978 , art. $3 .^{\circ}$ ).

Aparte de la presencia de las Diputaciones en el seno de los Entes preautonómicos debe valorarse el hecho de la exigencia de un amplio acuerdo de los Municipios de cada Provincia ( $2 / 3$ partes que representen al menos la mayoría del censo electoral de cada Provincia, en el art. 143, 2, y $3 / 4$ partes que representen así mismo al menos la mayoría del censo electoral de cada Provincia, en el art. 151). Si, como dijimos, las Provincias se configuran en nuestro Derecho constitucional como agrupaciones de Municipios, entendiéndose, por tanto, la comunidad provincial como una comunidad intermunicipal, el que en todo caso sea preciso contar con esos amplios respaldos municipales en cada Provincia de las que quieran constituir la Comunidad Autónoma, refuerza sin duda la idea de que ésta se configura en la Constitución como asociación de Provincias, aunque en el proceso de su establecimiento no intervengan ś́lo sus órganos ordinarios de gobierno y administración y se apele al voto directo de los Municipios que las componen o incluso de la población misma, directamente, en fórmulas de referéndum o a través de los parlamentarios nacionales elegidos en ellas.

Sobre la iniciativa del proceso autonómico, vid. el reciente trabajo de ALvarez CONDE, E.: Los titulares..., cit., supra. 
bleas estatuyentes-proponentes del artículo 146 de la Constitución en el procedimiento ordinario. $Y$ en el procedimiento especial del artículo 151, el referéndum de iniciativa tiene que dar un resultado afirmativo por mayoría absoluta de los electores de cada Provincia, aunque luego en estos casos la Asamblea estatuyente-proponente la formen solamente los parlamentarios de las Provincias correspondientes, lo que por lo demás podría explicarse distinguiendo lo que es la intervención de las Provincias en la decisión de asociarse y lo que es elaboración del Estatuto, que, al escogerse esta vía, se aceptaría dejar en las manos solamente de los parlamentarios (77).

En cuanto a las exigencias estructurales de la organización de las Comunidades Autónomas pluriprovinciales, sabido es que la Constitución solamente contiene condiciones en cuanto a las que se constituyan por la vía del artículo 151, y en estos supuestos, el artículo 152, al referirse a la Asamblea legislativa, exige que sea elegida por un sistema electoral que asegure la representación de las diversas zonas del territorio, en lo que muy bien puede verse una alusión a tomar en cuenta el origen interprovincial de las Comunidades. De hecho, en los dos Estatutos de Autonomía hasta ahora aprobados, aunque se deja a una ley regional la determinación ulterior del sistema electoral, provisionalmente se determinan como circunscripciones electorales los Territorios Históricos o Provincias (78). Claro que entonces las Provincias se toman como un todo unitario, sin

(77) A la postre nunca el Estatuto rector de la Comunidad Autónoma que se haya decidido constituir es obra exclusiva de las Asambleas estatuyentes-proponentes, ya que deben ser las Cortes Generales quienes finalmente mediante ley orgánica lo aprueben de forma definitiva. Y las Cortes pueden modificarlo evidentemente, si bien en el supuesto de la vía del artículo 151 no podrá perfeccionarse como ley si no se logra el consentimiento de los representantes 0 , al menos, del cuerpo electoral mismo de las Provincias afectadas. En el supuesto de la vía ordinaria del 143 y ss., las Cortes no necesitan constitucionalmente contar con tal consentimiento, pero políticamente es previsible que no introduzcan modificaciones en el Proyecto de Estatuto elaborado por la Asamblea regional estatuyente-proponente que puedan encontrar una fuerte oposición en la Región respectiva, proyectándose también aquí aunque no sea más que de hecho la sustancia paccionada con que los Estatutos de Autonomía regional se configuran o tienden a configurarse en la Constitución, como ya indicábamos, supra, en nota 56.

(78) Cfr. Estatuto Vasco, artículo 26 y disposición transitoria primera; Estatuto de Cataluña, artículo 31 y disposición transitoria $4 .^{2}$ Se recordará que los llamados Territorios Históricos en el Estatuto del País Vasco no son sino las Provincias de Alava, de Guipúzcoa y del Señorío de Vizcaya (y la de Navarra, si llegara a incorporarse a esta Comunidad Autónoma). El Estatuto gallego determina como circunscripción electoral, en todo caso, la Provincia (art. 11,4) y regula las primeras elecciones en la disposición transitoria primera sobre una base efectivamente provincial, aunque-como en los otros dos Estatutos-más con un criterio de representación política que de representación especial-territorial (sobre esta distinción, vid. PUNSET, R: El concepto de representación territorial..., cit.). 
tener en cuenta su naturaleza intermunicipal, y, desde luego, aplicándose un sistema de sufragio directo, que no toma en cuenta para nada a los órganos de representación de las correspondientes Provincias. Subsiste, sin embargo, de alguna manera, en definitiva, el carácter interprovincial de dichas Comunidades.

Pues bien, lo que más me interesa subrayar en este momento es que, al margen ya de toda esta problemática a la que acabamos de aludir, lo cierto es que la constitución de las Comunidades Autónomas no puede llevar consigo la desaparición de las Provincias, por las razones que expusimos en su momento acerca del carácter constitucionalmente necesario de estas Entidades. El proceso asociativo de constitución de la Comunidad Autónoma y de acceso por esa vía de las Provincias mismas al llamado autogobierno común, no puede entenderse como un proceso tan integrador que entrañe la desaparición o supresión de las Provincias correspondientes, al menos por sí mismo (79). Igual que cuando unos individuos o unas Entidades públicas o privadas se asocian no pierden por ello su personalidad característica, las Provincias conservarán aquí, por imperativo constitucional, su entidad propia, máxime incluso cuando el nuevo Poder público que van a lograr establecer-la Comunidad Autónoma-habrá de asumir competencias que correspondían anteriormente en su casi totalidad al Estado y que éste le transferirá cabalmente en razón de la configuración que la Constitución hace de aquel Poder; las Provincias previsiblemente seguirán con sus competencias e incluso éstas habrán de verse reforzadas al entrar en juego los principios constitucionales de la autonomía local y de la descentralización (artículo 103 de la Constitución en aplicación extensiva).

(79) Ocioso es recordar las posibilidades de remodelación provincial que mediante ley orgánica permite el artículo 141,1, aunque ya expusimos en su momento las dificultades prácticas que ello encontrará, fundamentalmente por la relevancia de la Provincia en las elecciones para las Cortes Generales. Por esa vía, con todo, podrían llegar a hacerse coincidir las Provincias catalanas con las Comarcas y procederse a remodelaciones del territorio de las Administraciones provinciales de otras Regiones que se vayan configurando definitivamente, de ser necesario. Sobre la imposibilidad de alterar las Provincias por los Estatutos de Autonomía, vid. Entrena Cuesta, R.: Curso.... cit., 35 , nota 15 .

Por lo demás, parece que según la Constitución, una vez implantada una Comunidad Autónoma, adquiere carácter de permanencia, sólo supeditado a las previsiones de su Estatuto de Autonomía. 


\section{Las Provincias-Comunidades Autónomas: estructura PROVINCIAL Y REGIMEN REGIONAL}

Veamos, en cambio, ahora lo que ocurre con las Comunidades Autónomas uniprovinciales. El que una Provincia-Región acceda a su autogobierno y se constituya en Comunidad Autónoma ha de tener lógicamente un significado y unos efectos en parte distintos a los que hemos visto deben producirse en las Comunidades pluriprovinciales. Aquí no podrá hablarse lógicamente de proceso asociativo (80) y los términos citados del artículo 143, 1, llevan de inmediato a entender que es la misma Provincia la que se constituye en Comunidad Autónoma en un proceso de auténtica transformación, al menos parcial, de una Entidad en otra. Si en las Comunidades pluriprovinciales el acceso de las correspondientes Provincias a su autogobierno mediante su constitución en Comunidad Autónoma no puede operarse sino por medio de una asociación que respete sus respectivas personalidades o por medio de una fusión, para establecer en ambos supuestos un nivel común de autogobierno-y la alternativa de la fusión debe excluirse por el carácter necesario de la Provincia en nuestra Constitución-, en el caso de la Comunidad uniprovincial no puede comprenderse cómo una Provincia vaya a poder acceder a su autogobierno si no es constituyéndose ella misma en Comunidad Autónoma: no se trata aquí de constituir un nivel de gobierno y administración con un espacio territorial diferente o con una representación comunitaria distinta, sino pura y simplemente de que la misma comunidad social y su misma estructura político-administrativa, que hasta ahora era solamente provincial, sometida al régimen propio de las Provincias, pase a recibir un tratamiento regional, sometida al régimen propio de las Comunidades Autónomas. La Provincia se transforma, pues, en Comunidad Autónoma, accediendo así a su autogobierno en el sentido que el artículo 143 de la Constitución emplea este término. No cabe, en con-

(80) Y ésta podría ser la razón de que los términos relativos al proceso asociativo interprovincial como generador de las Comunidades Autónomas, que aparecían en el texto del anteproyecto constitucional aprobado por la Ponencia de la Comisión de Asuntos Constitucionales del Congreso (cfr. supra), fuesen sustituidos por los términos más genéricos que emplea el definitivo artículo 143.1. los cuales permiten englobar tanto el supuesto de asociación entre Provincias como éste de conversión de una sola Provincia en Comunidad Autónoma. 
secuencia, en mi opinión, que subsistan por separado la Entidad provincial y la nueva Comunidad Autónoma uniprovincial (81).

Ahora bien, ¿no choca esta conclusión con el principio del carácter necesario, según la misma Constitución, de la Provincia como Entidad pública?

Hay que responder desde un principio que no, desde el momento en que es la misma Constitución la que parece imponernos dicha conclusión de que el establecimiento de la nueva Comunidad Autónoma deberá hacerse por transformación de la Entidad provincial. ¿Estamos entonces ante una excepción al carácter constitucionalmente necesario de las Provincias? Me parece que tampoco es exactamente esto y vamos a tratar de explicarlo.

Yo entiendo que la respuesta está en que la conversión de la Provincia en Comunidad Autónoma no equivale a la desaparición o supresión de la Provincia. Desde luego ésta no subsistirá por separado, pero tampoco desaparecerá: simplemente se modificará o trasmutará parcialmente, conservando sin embargo cuanto de su naturaleza esencial, conforme al ordenamiento constitucional, pueda conservar en la operación de su constitución en Comunidad Autónoma. Es decir, lo que deberá ocurrir en definitiva es que la Provincia-Entidad local se transforme en Provincia-Comunidad Autónoma (82).

El artículo 143, 1, de la Constitución contiene, en consecuencia, una excepción a la naturaleza ordinaria de la Provincia como Entidad o Administración local, sometida al régimen local por tanto. Pero nada más. En todos sus demás aspectos constitucionales, la

(81) Repárese bien en que según los términos del artículo 143, 1, el sujeto o sujetos del acceso al autogobierno que se obtiene mediante su constitución en Comunidad Autónoma son las Provincias mismas (o los Territorios insulares).

Son las Entidades correspondientes quienes ejercen el derecho a la autonomía regional porque se entiende sin duda que son ellas quienes representan a la colectividad regional de que en cada caso se trate. No comparto por ello la tesis que defiende Funes Martínez, Mariano: La Preautonomía Regional, separata de la Revista «Murcia», núm. 15, apartado IV, 2, para quien «tal vez procedería declarar inconstitucional cualquier intento de transformar o de hacer desaparecer a la Provincia, y se produ. ciría una complicación jurídica con el posible proyecto de una absorción de sus órganos de gobierno local por otra clase de institución. Por ello, entendemos que el espíritu de la Constitución es el de conservar aquélla sin perjuicio de que en su seno o abarcando su territorio se establezca una organización autonómica que, al igual que en las Regiones pluriprovinciales, atienda a los cometidos de dirigir la política regional y asumir las competencias que se transfieran del Estado y de la Diputación, y que ésta continúe siendo un ente administrativo con competencias más depuradas de las que ahora tiene».

(82) Sostiene la misma tesis Entrena Cursta, R.: Curso..., 35-36, donde reproduce, como ya hemos dicho en otra nota de este trabajo, las ideas expuestas en su colaboración al volumen en homenaje al Profesor Galvañ Escutia, cit., supra. 
Provincia debe mantenerse sustancialmente inmutada. $\mathrm{Y}$ ello porque, en rigor, para convertirse en Provincia-Comunidad Autónoma le basta con desprenderse de su sometimiento al régimen local para pasar a someterse al régimen jurídico propio de las Comunidades Autónomas, cuyos rasgos específicos más característicos ya hemos recordado en páginas anteriores. En lo relativo, pues, a su estructura institucional la Provincia puede-y debe-conservarse como tal - sin perjuicio de admitir en ella modificaciones compatibles con las exigencias constitucionales-, por la buena razón de que las excepciones deben interpretarse restrictivamente y si la conversión de una Provincia en Comunidad Autónoma es como hemos señalado un supuesto que excepciona la regulación común de las Provincias, ello ha de aplicarse restrictivamente de modo que esa excepción afecte al mínimo imprescindible, es decir, solamente a aquello en que sea incompatible la regulación común de las Provincias con el régimen propio de las Comunidades Autónomas. Y como ahora expondremos, en materia de estructura institucional, Ja Constitución no impone a las Comunidades Autónomas exigencia alguna que sea incompatible con la aplicación de lo que en cambio exige a las Provincias en ese aspecto.

E] resultado-y la solución, por ende, constitucional al problema de las Comunidades Autónomas uniprovinciales en su relación con las correspondientes Provincias-es, en definitiva, unas Comunidades Autónomas de especial naturaleza mixta, que tengan una estructura institucional provincial y se sometan, como las demás, al régimen jurídico regional o específico con carácter general de las Comunidades Autónomas.

Y decía que esto es así porque la Constitución no impone a las Comunidades Autónomas ninguna regla organizativa que pueda considerarse incompatible con las que, en cambio, exige implícitamente a las Provincias, según ya tuvimos ocasión de examinar con suficiente detenimiento.

En efecto, el texto constitucional sólo contiene algunas referencias a la organización institucional autonómica en relación con las Comunidades Autónomas que se constituyan por la vía del artículo 151-sean pluri o uniprovinciales-. Y para estos supuestos solamente se pide que dicha organización se base en una "Asamblea legislativa elegida por sufragio universal con arreglo a un sistema de representación proporcional que asegure, además, la representación de las diversas zonas del territorio, un Consejo de Gobierno 
con funciones ejecutivas $y$ administrativas y un Presidente, elegido por la Asamblea, de entre sus miembros, y nombrado por el Rey, al que corresponde la dirección del Consejo de Gobierno, la suprema representación de la respectiva Comunidad y la ordinaria del Estado en aquélla. El Presidente y los miembros del Consejo de Gobierno serán politicamente responsables ante la Asamblea" (artículo 152,1$)$.

Hay que resaltar al respecto que a diferencia de lo que la Constitución dispone expresamente en cuanto a las elecciones al Congreso, al Senado (Senadores provinciales) y a los Ayuntamientos (artículos 68, 1, 69, 2, y 140), no se exige aquí que las elecciones a la Asamblea regional sean hechas mediante sufragio igual y directo, bastando que sea un sistema de sufragio universal-que voten todos los electores de la comunidad-, proporcional y-nótese bien-que asegure la representación de las diversas zonas del territorio. Si al hablar de las Comunidades interprovinciales decíamos que estas zonas podrían y aún deberían ser al menos las Provincias correspondientes, aquí, en relación con las Comunidades uniprovinciales, esas zonas pueden y deben ser los Municipios o sus agrupaciones, en el sentido que explicamos al hablar en este mismo trabajo de las consecuencias de la exigencia constitucional de que las Provincias deben ser agrupaciones de Municipios. Y la elección podrá disponerse con arreglo a un sistema de elección directa o bien conforme a un sistema de elección indirecta de segundo grado, siendo este último el más conforme con la naturaleza constitucional de la Provincia, como también ya fundamentamos en su momento.

No hay en la Constitución base suficiente para sostener que un órgano dotado de potestad legislativa deba ser elegido siempre mediante sufragio directo. Si la Constitución lo hubiera entendido así lo habría explicitado en el artículo 152, 1, como norma mínima aplicable a las Asambleas legislativas regionales. No debe, pues, exigirse como constitucional lo que la Constitución bien pudo imponer y no lo hizo, marcando incluso una sensible diferencia con la regulación de otros supuestos análogos. $\mathrm{Y}$ por otra parte, aunque representen una pequeña proporción de Senadores, no se olvide que en la composición del Senado el artículo 69 prevé algunos elegidos por los órganos representativos de las Comunidades Autónomas, que obtendrán por tanto sus escaños en el Parlamento nacional por una elección de segundo grado.

Por otra parte, y comentando ya otro aspecto del problema, tam- 
poco hay nada incompatible con la estructura institucional de la Provincia en el hecho de que el artículo 152, 1-que, recuerdo de nuevo, solamente es aplicable a los supuestos de Comunidades Autónomas establecidas por el artículo 151-, parezca distribuir las funciones entre Asamblea y Consejo de Gobierno de modo que las ejecutivas y administrativas queden en manos de éste, y aquélla solamente disponga de poderes legislativos. Aparte que por ser el Consejo responsable ante la Asamblea, ésta mantendrá un control político sobre toda la actividad del Consejo y ostentará en consecuencia la auténtica dirección política de la Comunidad Autónoma, no hay por qué excluir a priori que la Asamblea pueda disponer de algunas potestades administrativas y, en concreto, de potestad reglamentaria, habida cuenta de que la atribución de funciones ejecutivas y administrativas al Consejo de Gobierno se hace en el artículo 152,1 , en unos términos que no implican necesariamente exclusividad, ni división rigurosa de poderes en ese sentido (83). Por tanto la Asamblea puede-y debe-cumplir perfectamente los cometidos que en el orden administrativo corresponden en las Provincias a las Diputaciones o demás Corporaciones representativas que la Constitución admite para su gobierno y administración. No es necesario que esa Asamblea, Junta o Corporación suprema retenga sin embar. go todas y cada una de las competencias que hoy tienen las Diputaciones de régimen común. Cabe traspasar muchas de ellas sin ningún problema al Consejo de Gobierno, conservando el control y la potestad normativa sobre ellas, instrumentos suficientes para asegurar la dirección y fiscalización que a la Asamblea no debe dejar de corresponderle.

Estimo conveniente insistir en que la Asamblea debe retener no sólo poderes de fiscalización, sino también de normación, bien sea por vía legislativa, bien por vía reglamentaria. Hay que tener en cuenta que en gran parte de las materias que sean de la competencia de la Comunidad Autónoma, ésta no va a disponer de poderes legislativos sino solamente ejecutivos o administrativos. Si en las que esto suceda la Asamblea no tiene más poderes que los de control, y todas las funciones reglamentarias corresponden al Consejo de Gobierno, la capacidad de participar en la efectiva ordenación de los asuntos regionales por parte de ella quedará muy limi-

(83) Aunque haya que comprender que pueda interpretarse esta norma como un pronunciamiento en favor de una forma parlamentaria de gobierno. En este sentido, vid. Argullol. Murgadas. Enrique: Organización administrativa de las Comunidades Autónomas, "DA», núm. 182, abril-junio 1979, 56. 
tada, con el consiguiente relegamiento de las minorías políticas o territoriales que no estén integradas o representadas en el Consejo de Gobierno. Es evidente por ello la conveniencia de atribuir a la Asamblea una potestad reglamentaria en las materias en que la Comunidad Autónoma no tenga competencias legislativas. Así se ha previsto en el Proyecto de Estatuto de Autonomía de Asturias (artículo 20,2). Y así parece que debería hacerse para no disminuir en las Provincias-Comunidades Autónomas el grado de participación que los representantes de los Municipios deben tener en la ordenación de los asuntos provinciales de cualquier clase de Provincia.

\section{CONCLUSION}

Hemos de terminar. La conclusión de cuanto hemos analizado en páginas anteriores es que para la Constitución todo parece indicar que las Comunidades Autónomas uniprovinciales deben configurarse como auténticas Provincias-Comunidades Autónomas, con estructura institucional propia de Provincia y régimen jurídico propio de Comunidad Autónoma. No imponiendo la Constitución en cuanto a las Comunidades Autónomas ninguna norma de organización institucional que sea contraria a cuanto expusimos como necesario y posible en cuanto a las Provincias, ha de considerarse aplicable a la Provincia-Comunidad Autónoma, en materia de elección de sus órganos superiores, lo que dejamos expuesto al referirnos a las Provincias desde una perspectiva constitucional. Diversas fórmulas de organización serán posibles, pero ninguna que deje de tener en cuenta la naturaleza intermunicipal de la Provincia en la composición del órgano $\mathrm{u}$ órganos superiores de su gobierno y administración como Comunidad Autónoma. En consecuencia, afirmar, como lo hace el Proyecto de Estatuto de Autonomía de Asturias, que la Junta General del Principado será elegida «mediante sufragio (...) directo (...) de los asturianos, con aplicación del sistema de representación proporcional personalizada» (artículo 22, 1). lo que supone un total desconocimiento de la naturaleza provincial del Principado y de los derechos de sus Concejos o Municipios, resulta difícilmente compatible con la Constitución vigente, por no decir abiertamente contrario a ella. Como lo es, igualmente, establecer (Disposición Transitoria Primera, 2, del mismo Proyecto de Estatuto) que «a efectos electorales, el territorio del Principado constituye una única circunscripción combinada con doce distritos uninominales cuya 
demarcación coincidirá con los partidos judiciales vigentes». Se refiere esta norma a la regulación de las primeras elecciones para la Junta General del Principado y, como puede verse, desconoce igualmente de modo absoluto los derechos provinciales de los $\mathrm{Mu}$ nicipios asturianos.

Discutible constitucionalidad material presenta asimismo, como ya expusimos, la actual regulación del Parlamento Foral de Navarra y de su Diputación Foral, ya que, aunque no tan flagrantemente como pretende hacerlo el proyectado Estatuto autonómico asturiano, el Real Decreto 121, de 26 de enero de 1978, ha marginado también no ya solamente a los Ayuntamientos, sino a los cuerpos electorales mismos de los Municipios navarros, del proceso de designación de los miembros del Parlamento y de los Diputados forales. Se siguen manteniendo las Merindades como circunscripciones electorales, pero no se tiene en cuenta a los Municipios como tales. A Navarra se la ha despojado también, en el fondo, del carácter intermunicipal con que la Constitución configura imperativamente a todas las Provincias españolas, incluidas las que se constituyan en Provincias-Comunidades Autónomas.

$\mathrm{Y}$ aunque en menor medida, pero no con mucha diferencia, puede afirmarse lo mismo, como lo hemos hecho al tratar específicamente de ello, en relación a los regímenes actualmente establecidos para Guipúzcoa, Vizcaya y las Provincias insulares.

Por lo demás, es obvio que siendo Navarra o Baleares, como Asturias o Murcia, Regiones uniprovinciales, habrá de aplicarse a todas ellas la conclusión principal de este trabajo.

Hemos de terminar. Precisamente en los días que ultimábamos la redacción de estas páginas, la prensa nacional daba cuenta de unas palabras pronunciadas por el actual Ministro de Administración Territorial (señor MARTín Vit.LA) en una reunión con 36 Presidentes centristas de Diputaciones y 14 portavoces del Partido del Gobierno en las restantes Corporaciones provinciales. "La Diputación-dijo el Ministro-es el Ayuntamiento de los Ayuntamientos» (84).

Vale la pena cerrar este trabajo con esta expresiva afirmación que viene a confirmar desde instancias oficiales el núcleo central de lo que aquí hemos tratado de explicar y fundamentar con criterios estrictos de interpretación jurídica. Cierto es que los órganos

(84) Diario $A B C, 4-11-80$, pág. 9. 
de gobierno y administración de las Provincias no tienen por qué ser necesariamente elegidos por los Ayuntamientos, pero sí por los Municipios. $\mathrm{Y}$ desde luego el sistema más plenamente coherente con la naturaleza determinada en la Constitución de 1978 para la Provincia sería el que hiciera, en efecto, de las Corporaciones provinciales auténticos "Ayuntamientos de Ayuntamientos". Y "Ayuntamiento de Ayuntamientos", o, al menos, representación de Municipios, ha de ser igualmente también la Junta, Parlamento o Asamblea legislativa de las Provincias-Comunidades Autónomas que se constituyan. 